\title{
Overview of 1998 Pesticide Sales in Alberta
}

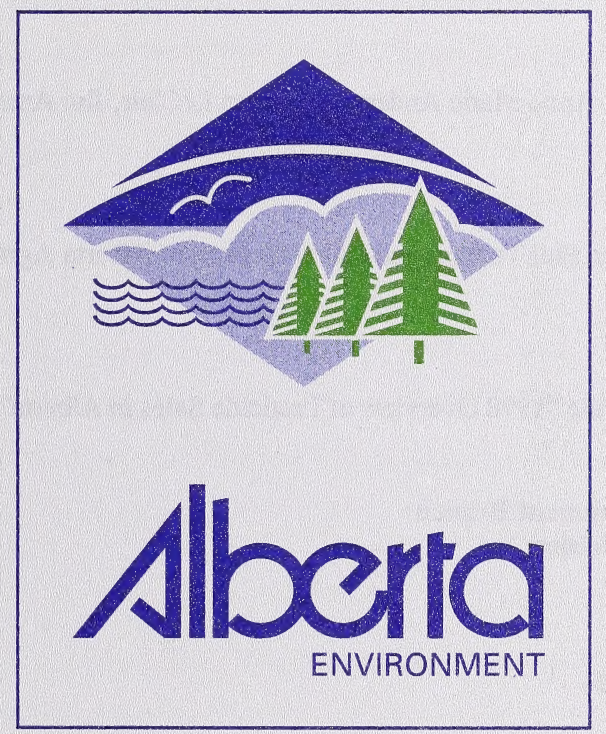

\section{June 2000}


Pub. No.: T/535

ISBN: $\quad$ 0-7785-1180-4 (Printed edition)

0-7785-1181-2 (On-line edition)

Website Address: www.gov.ab.ca/env/protenf/pesticide

\section{ACKNOWLEDGEMENTS}

The assistance and input of the following people was greatly appreciated during the preparation and compilation of this report:

Janet Mclean, Neil Wandler, Anne-Marie Anderson, Doreen LeClair, Jim Ames and Carol Thurston of Alberta Environment;

Sandra Cooke, Walter Yarish, Phil Thomas and David Neilson of Alberta Agriculture, Food and Rural Development.

More information regarding the " 1998 Overview of Pesticide Sales in Alberta" may be obtained by contacting:

\section{Municipal Program Development Branch}

Environmental Sciences Division

Environmental Service

Alberta Environment

$4^{\text {th }}$ Floor 9820 - 106 Street

Edmonton, Alberta T5K 2J6

Phone: (780) 427-9911 


\section{Overview of 1998 Pesticide Sales in Alberta}




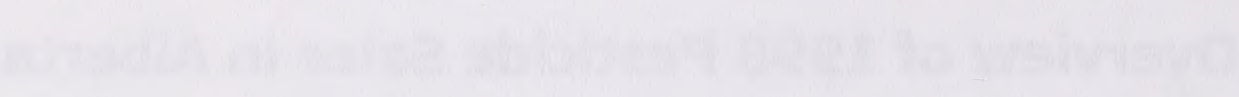




\section{EXECUTIVE SUMMARY}

Alberta Environment undertook the collection, consolidation and analysis of pesticide sales data from pesticide vendors in Alberta in 1998. The objective was to document the volume and types of pesticides sold in Alberta, and to prepare a general overview of the sales data in relation to sectors of use, types of use, chemical groupings, as well as geographic breakdowns by river basin, ecoregion, municipality and departmental regions. This project was a follow-up to a pesticide sales survey that last occurred in 1993. The overview follows the chemical grouping format used by Quebec in their reporting on pesticide sales in their province, and with the proposed National Pesticide Sales Database.

Pesticide sales data was requested from registered pesticide vendors and wholesalers in Alberta in early 1999, under the authority of the Environmental Protection and Enhancement Act and supporting regulations. Approximately $97 \%$ compliance with the sales data request was obtained. Sales data received was digitized or reformatted to a common database format. Six additional databases were constructed to assist with sorting and categorizing the sales records by chemical or geographic groups. The databases were brought into Access, where they were linked and various output was obtained.

In 1998, a total of $9300497 \mathrm{~kg}$ of pesticide active ingredient (ai) was sold in, or shipped into, Alberta. Pesticides sold into the Agriculture sector accounted for $95.8 \%$ of all pesticides sold, with the Commercial/Industrial sector accounting for $3.3 \%$ of sales, and the Domestic sector accounting for $0.8 \%$ of sales. The types of pesticides sold were predominantly herbicides, at $76.7 \%$. Adjuvants and surfactants made up the next largest category at $14.25 \%$. Insecticides made up $5.4 \%$ of sales, while fungicides made up $3.6 \%$ of sales.

Of the chemical groups, the Phosphonic Acids, Phosphinic Acids group was the largest at $29.9 \%$ of overall sales. However, in the Domestic sector, the Phenoxy Acids group dominated with $44.8 \%$ of pesticide active ingredient sold.

Looking at geographic distributions, the Oldman River basin had the highest overall sales at $20.3 \%$, followed by the Red Deer River basin at $\mathbf{1 8 . 8 \%}$ and the North Saskatchewan River basin at $15.8 \%$. Relative use intensities (based upon gross drainage area) were highest for the Oldman River basin, at 0.69 $\mathrm{kg}$ ai/ha.

When pesticide sales were sorted by ecoregion, the Aspen Parkland had the highest amount of sales, at $33 \%$, followed by the Moist Mixed Grassland at $22.6 \%$. This is partly attributed to the large size of the Aspen Parkland ecoregion in Alberta, and the large amount of agricultural land it encompasses.

Geo-administrative regions were also summarized, for use in program planning. The municipalities with the highest sales were the County of Lethbridge and the MD of Taber, at over $500,000 \mathrm{~kg}$ of active ingredient. Based upon their cropped acreage, pesticide use intensities of over $2.5 \mathrm{~kg}$ ai/ha were estimated. 
This compares to an overall provincial estimated pesticide use intensity (based upon cultivated land acreage) of $0.79 \mathrm{~kg}$ ai/ha. Other municipalities with over $300,000 \mathrm{~kg}$ ai of pesticide sales were the Counties of Red Deer, Vulcan, Vermilion River and Wheatland. Estimated pesticide use intensities for these municipalities ranged from 1.20 to $1.36 \mathrm{~kg}$ ai/ha. These municipalities may also serve as regional supply centres, so the use intensity estimates may be an overestimation.

Pesticide sales were also sorted by Alberta Environment regions. The Parkland and Prairie regions were the highest, at over $2.5 \mathrm{M} \mathrm{kg}$ ai each. Agricultural pesticide sales were also sorted by Alberta Agriculture, Food and Rural Development regions. Highest sales were in the Southern region at over $3.2 \mathrm{M} \mathrm{kg}$ of active ingredient, followed by the Northern region at $2.7 \mathrm{M} \mathrm{kg}$ ai.

The overview of pesticide sales data for Alberta has provided Alberta Environment and other agencies with the background data to enable comparisons to other regions, and to assist in ensuring that Alberta Environment has the appropriate regulatory framework in place for pesticides. The data will also be useful in identifying monitoring priorities for ongoing and upcoming monitoring programs. 


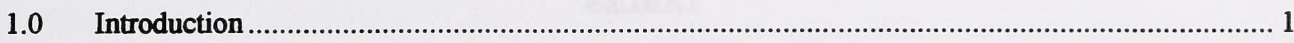

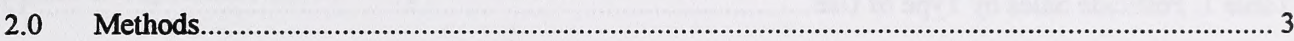

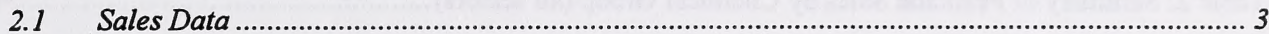

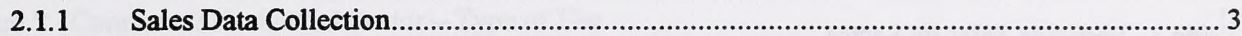

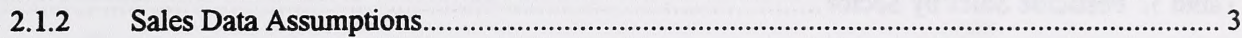

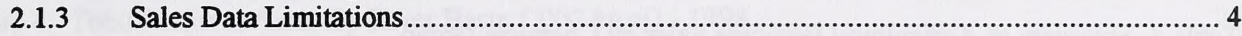

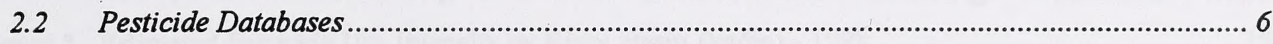

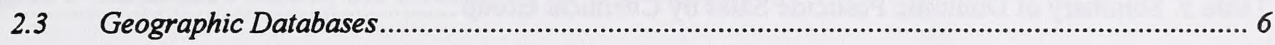

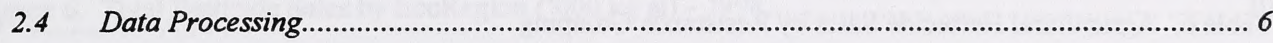

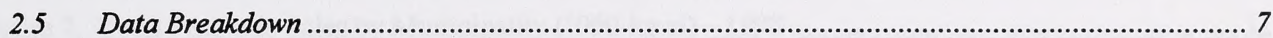

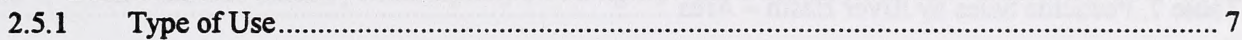

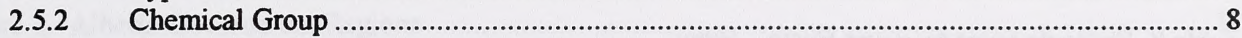

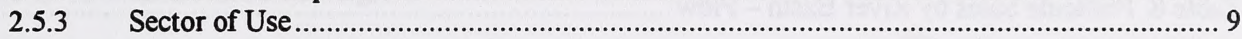

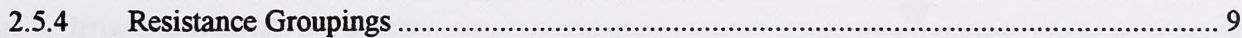

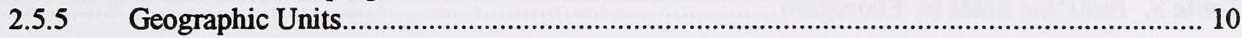

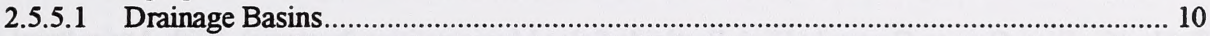

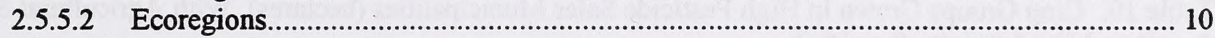

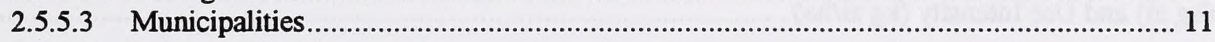

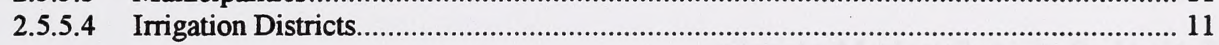

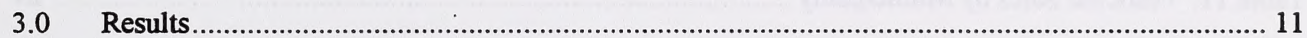

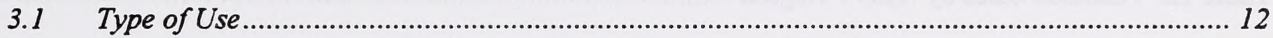

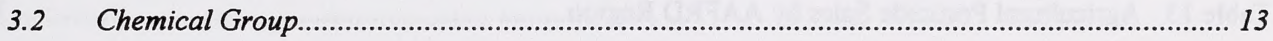

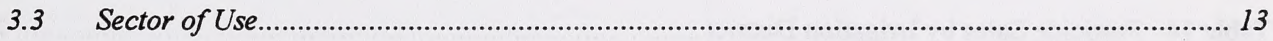

$3.4 \quad$ Herbicide Resistance Groups ....................................................................................... 18

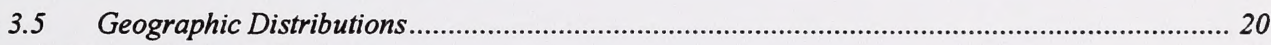

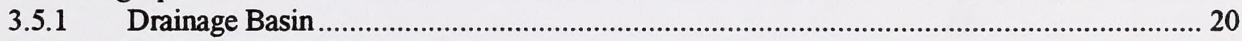

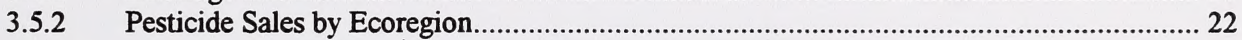

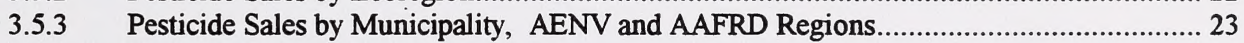

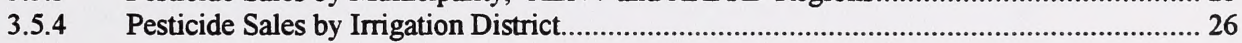

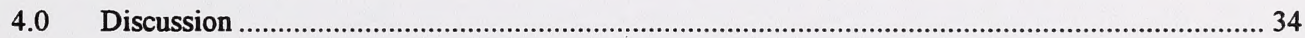

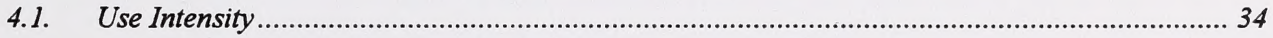

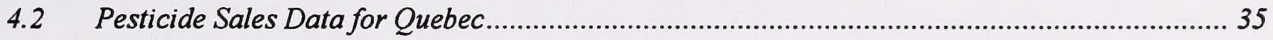

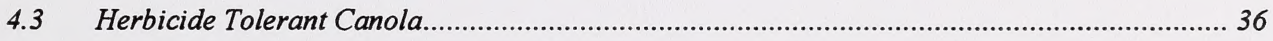

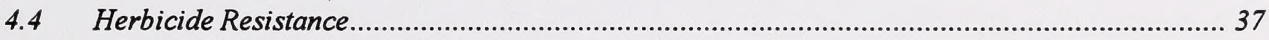

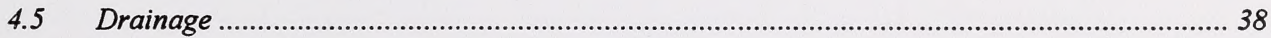

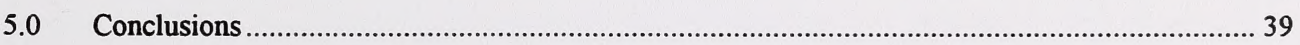

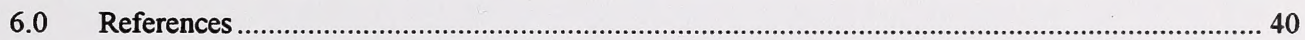

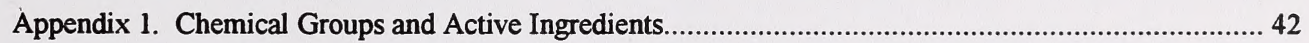

Appendix 2. Herbicide Groups Based on Sites of Action for Resistance Management........................... 56 


\section{TABLES}

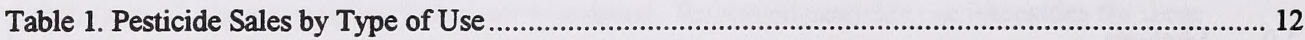

Table 2. Summary of Pesticide Sales by Chemical Group (all sectors) ................................................ 13

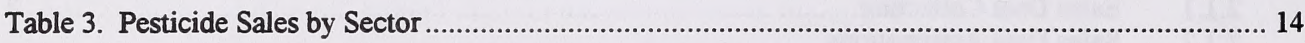

Table 4. Summary of Agricultural Pesticide Sales by Chemical Group ............................................ 15

Table 5. Summary of Domestic Pesticide Sales by Chemical Group .................................................. 17

Table 6. Agricultural Herbicide Sales by Resistance Grouping ...................................................... 18

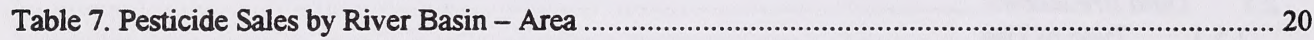

Table 8. Pesticide Sales by River Basin - Flow …....................................................................... 21

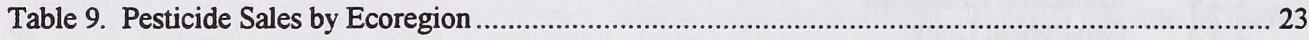

Table 10. Crop Groups Grown in High Pesticide Sales Municipalities (hectares), With Agricultural Sales

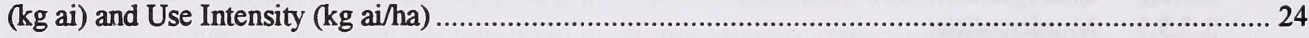

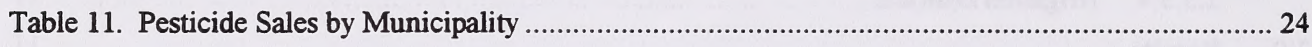

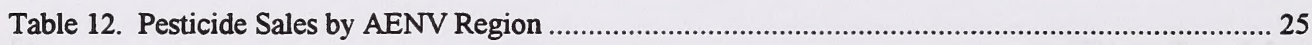

Table 13. Agricultural Pesticide Sales by AAFRD Region ............................................................... 26

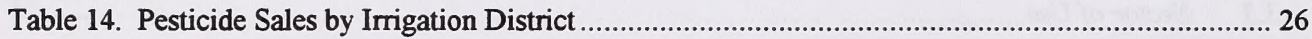




\section{FIGURES}

Figure 1. Agriculture Sector - Type of Use ............................................................................... 14

Figure 2. Domestic Sector - Type of Use …................................................................................. 16

Figure 3. Commercial/Industrial Sector - Type of Use ................................................................. 18

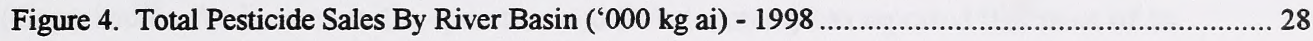

Figure 5. Estimated Pesticide Use Intensity by River Basin (kg/ha) - 1998...................................... 29

Figure 6. Total Pesticide Sales by EcoRegion ('000 kg ai) - 1998 .................................................. 30

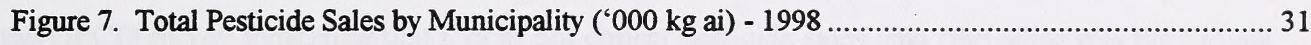

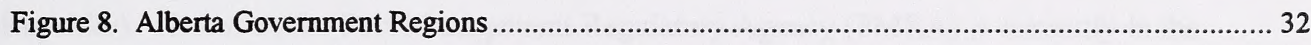

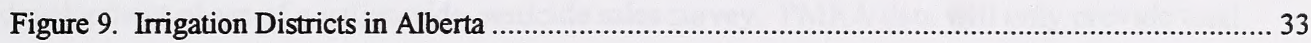


Digitized by the Internet Archive in 2015 


\subsection{Introduction}

Pesticide use statistics are becoming a valuable piece of information worldwide for regulatory and monitoring agencies in order to enable more efficient use of resources in the regulation of pesticides, and in the monitoring of pesticides in various environmental matrices. The OECD (Organization for Economic Co-operation and Development) has reported that most of its member countries collect pesticide sales or use information for various purposes (OECD, 1999).

Because detailed pesticide use information is extremely expensive to assemble, most jurisdictions use pesticide sales information as surrogate data. Canada is one of two countries that responded to the OECD survey indicating that it does not collect pesticide sales data (the other was the Slovak Republic). However, the Pest Management Regulatory Agency (PMRA) is currently in the development phase of a nationwide pesticide sales survey. PMRA data will only provide total provincial sales, which is not sufficient to meet our needs, but will be important in helping to ensure accurate accounting. The state of California, however, collects detailed pesticide use data by active ingredient, crop and acreage, primarily for their agricultural sector (California Department of Pesticide Regulation, 1999).

Alberta Environment collected pesticide sales information for the period 1988-1993 from major line companies (Cotton and Byrtus, 1995), and used this information to assist in the development of a major surface water monitoring program conducted from 1995-1996 (CAESA, 1998).

Although the data was limited to agricultural product sales, and limited to approximately $50-60 \%$ of the total agricultural sales, it did provide trend information on certain products. It also provided a geographic perspective on pesticide sales, which was important for determining monitoring locations. Subsequent to that report, data on 1993 domestic pesticide sales was also obtained from major distributors and retailers, and this unpublished information was used in the development of a factsheet on pesticide use in Alberta (AENV, 1998a).

Alberta Environment undertook a five-year update for 1998 pesticide sales, encompassing a more comprehensive data collection process. Alberta Environment, under the Environmental Protection and Enhancement Act and supporting regulations, has the authority to request pesticide sales records from wholesale and retail vendors to enable enforcement actions, as well as for the consolidation of data to enable efficient management of pesticides in Alberta. For the 1998 sales project, vendors of agricultural, domestic, livestock, commercial and industrial, and structural pest control products were surveyed. The data received was inputted, and pesticide sales were 
broken down by: (1) sector of use; (2) chemical group; (3) resistance groupings; and (4) geographic distribution by either drainage basin, ecoregion, municipality or irrigation district. As this data is more comprehensive than that collected in 1993, direct comparison to the 1993 data is not possible.

The data in this overview will assist Alberta Environment and other provincial and federal agencies in comparisons of pesticide sales/usage information. It will help to identify monitoring priorities for ongoing and upcoming monitoring programs. It will also assist Alberta Environment in ensuring that the appropriate regulatory framework is in place for the pesticides in current use in Alberta.

The specific objectives of this project were:

1. To assemble pesticide sales records representing pesticide use for the calendar year 1998 .

2. To categorize pesticide sales by chemical group, sector of use, and geographic distribution 


\subsection{Methods}

\subsection{Sales Data}

\subsubsection{Sales Data Collection}

Alberta Environment maintains a registry of pesticide vendors that retail restricted and commercial registered pesticide products, as well as wholesale distributors of domestic class products. This registry is maintained as a component of the Alberta Environment Environmental Management System, which tracks many of the approvals and registrations issued by Alberta Environment that fall under the Environmental Protection and Enhancement Act. Under the authority of this Act and its supporting regulations, AENV can request pesticide sales records from vendors. In December of 1998, a preliminary outline of the data collection process was sent to all registered vendors in Alberta, along with a copy of the factsheet "Pesticide Use in Alberta" (AENV, 1998a). In early February of 1999, the primary data request letter was sent out to all registered vendors, or head offices of registered vendors (254 letters). Data was received from the vendors in hard copy and digital formats. Non-compliers were sent a formal request letter from regional directors of AENV in Nov/Dec of 1999. Overall compliance at the time of this writing was $97 \%$. This process also enabled Alberta Environment to update its vendor registry, and identify those vendors who were no longer involved in selling pesticides.

Hard copy records were manually inputted into a standardized database file, while digital files were converted to the standardized database (dBASE V) format, which consisted of vendor approval number, product registration number (PCP No.), quantity sold in litres or kilograms and sector of use. Individual vendor data files were consolidated into a single sales database, which contains just over 69,000 records.

\subsubsection{Sales Data Assumptions}

There are some major assumptions involved in using pesticide sales data as a surrogate for pesticide use. The primary one is that products sold are used in the year of sale. While this may be the case for most agricultural products, this may not be the case with domestic products. Domestic products are usually shipped by case lots, so unless point of sale information was obtained, only case lot quantities are recorded. Also, records from wholesale distributors (agricultural and domestic) rarely account for inventory carryover (winter period), unless product is returned to the distributor. Some data comparison was done for a major agricultural distributor and some of the retail outlets that they had shipped to. It was quite apparent from comparing the 
records that some product sold in any one year comes out of overwintering inventory, and some product that is unsold goes into overwintering inventory. Therefore, depending upon wholesale records alone does not guarantee an accurate picture of pesticide sales or use.

\subsubsection{Sales Data Limitations}

Sector Representation

The data from vendors that are primarily agricultural suppliers may have contained sales to the landscape industry, the industrial sector, municipal governments, golf courses and other nonagricultural sectors, which were not identified. As a result, the agricultural sector may be overrepresented, while the other sectors may be under-represented.

\section{Treated Seed}

Sales of fungicide and insecticide treated seed was not captured in this survey. However, sales of seed treatment compounds to farmers for on-farm treatment and to seed cleaning plants were covered. Most of the commercial seed treatment facilities that treat registered and specialty seeds (e.g., Roundup Ready canola, Liberty Link canola) would have had their pesticide usage covered if they had purchased their seed treatment products in Alberta. However, treated seed from out of province suppliers would not have been covered. The collection of treated seed sales data was beyond the scope of this project, particularly as seed distribution is often done by seed vendors or seed divisions rather than agricultural chemical divisions of the line companies. Estimates of herbicide tolerant canola planted in 1998 was approximately $61 \%$ of the 1760445 hectares planted to canola in Alberta, based upon insured seeded acres (Thomas 2000). Virtually all herbicide tolerant canola is treated with fungicide/insecticide (carbathiin/lindane mainly)(Thomas, 2000).

\section{Geographic Resolution}

Since 1993, the major agricultural input suppliers in Western Canada have been consolidating their operations, through closure of grain elevators and opening of farm supply centres, which are generally Crop Protection Institute (CPI)-audited warehouses. This has resulted in fewer sales outlets throughout Alberta, with a resulting loss of geographic discrimination in regards to sales information. For 1998, this has been partially compensated for by the inclusion of independent agricultural input suppliers, which were not included in the 1988-1993 sales survey (Cotton and Byrtus, 1995). 


\section{Vendor List}

The vendors surveyed were based upon the 1998 Pesticide Vendor Registrations (Blue List) that Alberta Environment publishes each year (AENV, 1998b). Because certain sectors are exempt from requiring a vendor registration, this survey does not address all pesticide sales in Alberta. For example, many of the livestock products have been exempted from vendor registration requirements, and although the Blue List does show a number of livestock vendors, this is because they also retail strychnine-based rodenticides, for which a vendor registration is required. Therefore, the livestock product information is not complete. Also, disinfectants, anti-microbial products and wood preservatives are exempted from requiring a vendor registration, so there is virtually no sales data on those products.

\section{Domestic Products}

The sales records obtained from the agricultural and industrial sectors were often very accurate in terms of product sold, as they were obtained from the point of sale system for each outlet. Only one domestic distributor provided point of sale records, while most domestic records were based upon product shipped to various outlets (usually case lots) and not point of sale records. Because it is not known how much product came out of individual stores inventory in the spring, and went into inventory in the fall, it was assumed that the product shipped to the various domestic retail outlets in 1998 was sold in 1998.

In the domestic sector, pet care products sold in Alberta were not identified in this survey, nor were lawn and garden or household pesticides shipped into Alberta from small distributors elsewhere. Some miscellaneous household (indoor) pesticides were also missed in this survey, as they are classified as Schedule 4 products, which have been exempted from the provincial regulations as far as requiring wholesale vendor registrations, or retail dispenser certification.

\section{Non-Specific Records}

Some vendors (distributors/wholesalers) were unable to identify retail outlets for their shipments for a variety of reasons. These sales data were identified as "Alberta", and as a result, would not be included in any geographical breakdown. These records would, however, be included in chemical group summaries. 


\subsection{Pesticide Databases}

In order to consolidate pesticide formulation sales information down to active ingredient and then to chemical group, two separate databases were also incorporated. The first of the pesticide databases was the pesticide Product database, which was obtained from the PMRA in early 1998, and updated with 1998 registrations as well as registrations under the Fertilizer Act for domestic fertilizer blends containing pesticides. This database has information required for this project on the product registration number, active ingredient, guarantee, as well as product name, registration status, etc. This database has 13,286 records. The second pesticide database was the Active database, which included active ingredient codes, active ingredient names, and to which chemical family, chemical group and resistance groupings were added. There is a total of 555 records in this database, however this includes disinfectants, antimicrobials and a few active ingredients that are no longer registered or sold in Canada.

\subsection{Geographic Databases}

Four databases were used to identify the geographic distribution of pesticide sales information. The primary database was the Vendor database, which included the vendor registration number, along with the vendor name and city, town, village or hamlet that the vendor was located in or nearest to. As a number of sales records were received for vendors that do not require vendor registrations in Alberta (primarily domestic retail vendors), dummy vendor numbers were also generated for these. Dummy vendor numbers were also generated for all municipalities in Alberta to enable geographic identification of minor vendors, or sales records to end users. Another major database was the City database, which lists all of the municipalities in Alberta. Associated with each municipality was the corresponding reference for rural municipality, drainage basin, ecodistrict and irrigation districts. Secondary databases included Drainage (which cross-referenced drainage basin and river basins), and Ecoregion (which cross-referenced ecodistrict and ecoregions - based upon information provided by Alberta Agriculture, Food and Rural Development).

\subsection{Data Processing}

The databases were imported into Microsoft Access for linking and querying. The databases were linked by related fields to calculate active ingredient values, and subsequent data groupings by chemical group, sector of use, and geographic distribution (see Cotton and Byrtus, 1995 for an example of how the calculations were done). Conversion of formulated product sales to $\mathrm{kg}$ of active ingredient (ai) is a common means of expressing pesticide sales/use in other jurisdictions 
(Gregoire, 1997), although actual reporting is often based upon chemical group or by sector of use. This document will report pesticide use by chemical group in order to be consistent with data reported by the Province of Quebec (Gregoire, 1997; Gorse, 1999), and with the reporting format agreed upon by the National Pesticide Sales Database Working Group.

Assumptions were made with respect to pesticide formulations, such as the specific gravity of all pesticides being 1.0. Biological pesticides such as Bacillus thuringiensis formulations will be reported as units of mass sold $(\mathrm{kg})$, based upon an assumption of $100 \%$ active ingredient. As biological pesticides are registered based upon toxicological units (e.g., BIU, AAU, ITU, etc) and not percentage active ingredient, they will be represented as total mass sold.

Products that contain more than one active ingredient were assigned an extension number to the PCP number for each of the active ingredients involved in both the sales and product databases.

This enabled the use of the existing registration numbers with only a minor modification, and also enabled the software used for the data processing to accurately identify each component of a formulation. However, this resulted in additional records being added to the sales database to account for each active ingredient in a formulation (approximately 20,000 records).

\subsection{Data Breakdown}

In order to simplify the analysis of the data, consolidation of the data based upon type of use, chemical group and sector of use was undertaken.

\subsubsection{Type of Use}

Under the PCP Act, pesticides are classified into 39 product types (herbicides, insecticides, fungicides, etc) of products, which reflect their type of use. For the purpose of this document, the categories have been reduced to 6 primary types of use. All of the active ingredients identified in sales made in Alberta in 1998 are included in one of the types of use listed here. For those active ingredients that have multiple types of uses (such as thiram, which is a fungicide and a vertebrate repellent), the product is listed under its primary usage for Alberta.

- Herbicides and plant growth regulators

- Insecticides, acaracides, repellents,

- Fungicides

- Vertebrate control products and vertebrate repellents

- Adjuvants/surfactants

- Other: (Soil fumigants, wood preservatives, disinfectants, anti-microbials) 
As the primary focus of this survey was on traditional pesticides, and not anti-microbial or disinfectant pesticides, sales data from industrial and domestic cleaning agents were not obtained or included, although these are also registered under the PCP Act. Adjuvants and surfactants are widely used in the agricultural industry in Alberta, so these records were included as a separate category.

\subsubsection{Chemical Group}

The chemical groupings (listed below) used for this overview are based primarily upon the groups established by the National Pesticide Sales Data Base, using an interim list dated February of 2000 (Appendix 1). This list is still under review, and could be subject to further changes. This list is derived from a variety of sources, with the main source being the list used by Quebec in their pesticide sales groupings (Gorse, 1999), although there are a number of minor differences in the chemical groups used here and by Quebec. Several of these groups contain more than one chemical family. For example, the Amides, Anilines group contains compounds from the anilides, amides and benzamides families.

\section{Chemical Groupings Used In This Overview}

- Alcohols

- Amides, Anilines

- Amino Acids

- Ammoniums, Quaternary

- Aryloxyphenoxyl Acids

- Azoles, Diazoles, Oxazoles, Thiazoles, Triazoles

- Bacillus thuringiensis species

- Benzimidazoles, Phenylpyrroles

- Benzonitriles, Nitriles

- Carbamates

- Carboxylic Acids

- Chlorophenols

- Chromenones

- Cyclohexanedione Oximes

- Diazines, Quinoxalines, Morpholines

- Dicarboximides, Oxathiin

- Dithiocarbamates

- Fatty Acids

- Halogenated Hydrocarbons

- Hydrocarbons

- Indanediones
- Inorganic Coppers

- Inorganic Zincs

- Inorganics, Other

- Microbials (Other than Bt)

- Miscellaneous (Non-classified)

- Nitro Derivatives

- Oils, Mineral and Vegetable

- Organic Acids

- Organochlorines

- Organometallics

- Organophosphorous

- Phenols

- Phenoxy Acids

- Phosphonic Acids, Phosphinic Acids

- Phthalic Acids

- Pyrethroids, Pyrethrins

- Pyridines

- Sulfonylureas, Uracils

- Thiocarbamates

- Triazines, Triazinones, Tetrazines

- Urea Derivatives 


\subsubsection{Sector of Use}

The intent of categorizing the sales by sector of use was to attempt to differentiate between various sectors and their relative usage of pesticides in Alberta. Initially, it was thought that the sales could be differentiated by product and by the vendor. For products such as home and garden pesticides (Domestic sector), and products used on livestock (Livestock sector), this was relatively easy. However, the sales records indicated that several of the vendors who sell agricultural products primarily also sold herbicides that were primarily for turf, non-cropland, right of way (ROW) or landscape usage (Commercial/Industrial), and would not be used for agricultural production purposes, except perhaps for pasture renovation. These records were categorized as Commercial/Industrial.

Some products have multiple use locations such as agriculture, landscaping or ROW maintenance. As the end use for these products could not be distinguished, these purchases at agricultural vendors have been included under the Agricultural sector. The resulting breakdowns therefore, are simplified and may not accurately reflect actual usage in Alberta. Better delineation of this information may occur over the next five years, as AENV is undertaking industry sector surveys for certified applicators and registered services to estimate sector use.

The sectors of use used in this report include:

- Agricultural

- Domestic

- Commercial/Industrial (includes forestry, ROW, landscaping, golf courses, municipal)

- Livestock

- Structural.

\subsubsection{Resistance Groupings}

Herbicide resistance is a major issue in western Canada crop production, because of the widespread use of herbicides. In order to assist in identifying patterns in the use of products with known resistance in Alberta, each active ingredient was classified by its resistance grouping by site of action as outlined in PMRA Regulatory Directive DIR99-06 (PMRA, 1999). The herbicide resistance groupings in this document are based upon the Weed Science Society of America classification. There are 28 resistance groups identified for herbicide active ingredients currently registered in Canada. This document also classifies the insecticides and fungicides with 
known resistance, although insecticide and fungicide resistance is not a major issue in Alberta at this time.

\subsubsection{Geographic Units}

\subsubsection{Drainage Basins}

There are 14 major drainage basins that are identified in Alberta. Within these drainage basins are numerous sub-basins, which define the watersheds of major tributaries. In order to assist the interpretation of pesticide monitoring data for Alberta, which is reported by major basin, and sometimes by sub-basin, identification of overall pesticide usage by drainage basin is required. All of the municipalities in the City database were identified as to their respective sub-basin. The major drainage basins in Alberta used for this report are:

- Athabasca River

- Battle River

- Beaver River

- Bow River

- Hay River

- Milk River
- North Saskatchewan River

- Oldman River

- Peace River

- Red Deer River

- Sounding Creek

- South Saskatchewan River

\subsubsection{Ecoregions}

There are ten major ecoregions in Alberta, which contain a total of 282 ecodistricts. To link pesticide sales to the various ecoregions in Alberta, each municipality in the City database was located to a specific ecodistrict, which was then linked to the respective ecoregion in the Ecoregion database. The detailed maps used to determine municipality location in relation to ecodistrict were obtained from AAFRD (1999a) and Strong and Thompson (1995). The ecoregions identify different ecological zones within Alberta, which are influenced by soil type, climate, physiography, water, fauna, land use, and vegetative cover (ESWG, 1995). The ecoregions of Alberta are:

- Aspen Parkland

- Athabasca Plain

- Fescue Grassland, Cypress Hills

- Mixed Boreal Upland

- Mixed Grassland
- Moist Mixed Grassland

- Northern Alberta Uplands

- Peace Lowland/Boreal Transition

- Subalpine and Alpine

- Western Alberta Uplands 


\subsubsection{Municipalities}

There are 88 municipalities (rural municipalities, cities and national parks) in Alberta. Pesticide sales were allocated to the municipality in which the vendor was located for data analysis by geopolitical boundaries. Roll-ups of municipalities were used to determine regional sales information for both AENV and Alberta Agriculture, Food and Rural Development regional boundaries. In most situations, agricultural sales made at a vendor located in a city were consolidated to the surrounding rural municipality (e.g., Camrose).

\subsubsection{Irrigation Districts}

There are 13 irrigation districts in Alberta, which are supplied primarily from rivers originating in the Rocky Mountains (Belly, St. Mary's, Oldman and Bow Rivers). They vary in size from the smallest (Ross Creek) at 490 ha to the largest (Eastern ID) at 113548 ha. Irrigation districts comprise both irrigated and non-irrigated land, and it is not possible with this dataset to differentiate between pesticides use on dryland or irrigated land. Also, vendor locations may or may not fall within the boundaries of an irrigation district, therefore sales in the irrigation districts of Alberta is not an accurate picture of pesticide use in the districts. More detailed surveys of actual pesticide use under dryland and irrigation conditions are required to verify these estimates. For this study, it was possible to identify specific products that would be used on specialty crops (sugar beets, potatoes, corn) in this region, as well as broader spectrum products that are sold within the irrigation districts. The irrigation districts are:

- Mountain View

- Leavitt

- Aetna

- United

- Magrath

- Raymond

- Lethbridge Northern
- Taber

- St. Mary River

- Ross Creek

- Bow River

- Western

- Eastern

\subsection{Results}

In 1998, a total of $9300497 \mathrm{~kg}$ of active ingredient was sold in Alberta. The sales data are broken down as follows. 


\section{$3.1 \quad$ Type of Use}

Herbicides and plant growth regulators (PGR's) made up the majority of pesticides sold in Alberta, at $76.7 \%$ (Table 1). Although insecticides made up a greater proportion than fungicide sales in 1998, this was primarily attributed to an extensive Lygus bug outbreak, which resulted in over 1.4 M acres being sprayed throughout Alberta. As insecticide use was unusually high in 1998 , it is expected that fungicide sales would exceed insecticide sales in non-outbreak years.

Table 1. Pesticide Sales by Type of Use

\begin{tabular}{|l|r|c|}
\hline Type of Use & Kg ai & Percentage (\%) \\
\hline Herbicides, PGR's & 7130643.1 & 76.67 \\
\hline Insecticides, Acaracides, Repellents & 501044.2 & 5.39 \\
\hline Fungicides & 338628.1 & 3.64 \\
\hline Vertebrate Control Products and Vertebrate Repellents & 1594.5 & 0.02 \\
\hline Adjuvants and Surfactants & 1325320.1 & 14.25 \\
\hline Other & 3267.8 & 0.04 \\
\hline Totals & $\mathbf{9 3 0 0 4 9 7 . 8}$ & $\mathbf{1 0 0}$ \\
\hline
\end{tabular}

Vertebrate control products and repellents made up a very small percentage of pesticide sales, at less than $\mathbf{0 . 0 2 \%}$. The majority of this was for products used for controlling Richardson's ground squirrel and pocket gophers.

Adjuvants and surfactants made up the second largest group, in terms of percentage of sales. These compounds are often packaged with herbicides, and are used to enhance the effectiveness of the herbicides on the target weed(s). Although they have been categorized as a separate type of use, because they are virtually always used in conjunction with a herbicide, they could be considered a component of the Herbicide group.

The "Other" category includes sales for products that do not fit the named categories, and for which only a limited number of sales records were received. This category includes wood preservatives, disinfectants, slimicides and soil fumigants. As the disinfectants and slimicides are exempted under the provincial pesticide regulations, and the focus of the sales survey was primarily on the traditional pesticides, very little information on these products was obtained. 
The sales records were also broken down by chemical group, as defined by the National Pesticide Sales Database groupings (Appendix 1). The chemical group with the largest proportion of sales was the Phosphonic Acids, Phosphinic Acids group at $29.9 \%$, followed by the Phenoxy Acids at 18.7\%. The next groups were the Thiocarbamates, Oils, Mineral and Vegetable, and Nitro Derivatives in the $7-8 \%$ range. These five groups consist of the major herbicides (and adjuvants/surfactants) used in Alberta. The remaining chemical groups were all under $5 \%$, and 27 of the 42 chemical groups were under $1 \%$ of total sales.

\subsection{Sector of Use}

Pesticide sales broken down by sector of use are listed in Table 3. As expected, agricultural use dominates pesticide sales in Alberta at $95.8 \%$. The next sector was the Commercial/Industrial sector at $3.3 \%$. Domestic pesticide sales made up only $0.77 \%$ of total sales by active ingredient. Livestock and Structural sectors combined made up only $0.1 \%$ of all sales.

Table 2. Summary of Pesticide Sales by Chemical Group (all sectors)

\begin{tabular}{|l|r|c|}
\hline Chemical Group & \multicolumn{1}{|c|}{ Kg ai } & Percentage (\%) \\
\hline Phosphonic Acids, Phosphinic Acids & 2783525.9 & 29.93 \\
\hline Phenoxy Acids & 1742269.9 & 18.73 \\
\hline Oils, Mineral and Vegetable & 771285.9 & 8.29 \\
\hline Thiocarbamates & 734218.3 & 7.89 \\
\hline Nitro Derivatives & 682993.8 & 7.34 \\
\hline Carboxylic Acids & 431121.9 & 4.64 \\
\hline Hydrocarbons & 371556.8 & 4 \\
\hline Benzonitriles, Nitriles & 306055.5 & 3.29 \\
\hline Organophosphorous & 279196.2 & 3 \\
\hline Cyclohexanedione Oximes & 187367.4 & 2.01 \\
\hline Dicarboximides, Oxathiin & 157861.9 & 1.7 \\
\hline Inorganics, Other & 146084.0 & 1.57 \\
\hline Aryloxyphenoxyl Acids & 136306.8 & 1.47 \\
\hline Alcohols & 103559.3 & 1.11 \\
\hline Dithiocarbamates & 98202.2 & 1.06 \\
\hline Organochlorines & 68520.9 & 0.74 \\
\hline Miscellaneous, Non-classified & 40790.6 & 0.44 \\
\hline Bacillus thuringiensis species & 39353.3 & 0.42 \\
\hline Ammoniums, Quaternary & 36352.1 & 0.39 \\
\hline Sulfonylureas, Uracils & 30834.9 & 0.33 \\
\hline Pyridines & 23733.0 & 0.26 \\
\hline Triazines, Triazinones, Tetrazines & 23364.0 & 0.25 \\
\hline Azoles, Diazoles, Oxazoles, Thiazoles, Triazoles & 20527.6 & 0.22 \\
\hline Benzimadazoles, Phenylpyrroles & 18663.0 & 0.2 \\
\hline Urea Derivatives & 18696.8 & 0.2 \\
\hline
\end{tabular}




\begin{tabular}{|l|r|c|}
\hline Chemical Group & \multicolumn{1}{|c|}{ Kg ai } & Percentage (\%) \\
\hline \hline Amides, Anilines & 14482.5 & 0.16 \\
\hline Carbamates & 12334.8 & 0.13 \\
\hline Fatty Acids & 7940.3 & 0.09 \\
\hline Diazines, Quinoxalines, Morpholines & 3875.9 & 0.04 \\
\hline Pyrethroids, Pyrethrins & 2935.8 & 0.03 \\
\hline Halogenated Hydrocarbons & 1850.9 & 0.02 \\
\hline Inorganic Coppers & 1230.4 & 0.01 \\
\hline Amino Acids & 1125.3 & 0.01 \\
\hline Phthalic Acids & 1035.0 & 0.01 \\
\hline Phenols & 805.7 & 0.01 \\
\hline Chromenones & 183.1 & 0.0 \\
\hline Organic Acids & 148.0 & 0.0 \\
\hline Inorganic Zincs & 89.2 & 0.0 \\
\hline Organometallics & 16.3 & 0.0 \\
\hline Indanediones & 2.1 & 0.0 \\
\hline Chlorophenols & 0 & 0.0 \\
\hline Microbials - Other than Bt & 0 & 0.0 \\
\hline Totals & 9300497.3 & $\mathbf{1 0 0}$ \\
\hline
\end{tabular}

Further breakdown of the sector sales by type of use was conducted to assess if the overall trends in type of use was consistent within each sector. Figures 1-3 show the breakdowns for each sector.

Table 3. Pesticide Sales by Sector

\begin{tabular}{|l|r|c|}
\hline Sector & Kg ai & Percentage (\%) \\
\hline Agriculture & $\mathbf{8 9 1 3 9 8 1 . 7}$ & 95.84 \\
\hline Domestic & 72024.4 & 0.77 \\
\hline Commercial/Industrial & 304881.6 & 3.28 \\
\hline Livestock & 6373.2 & 0.07 \\
\hline Structural & 3236.8 & 0.03 \\
\hline Totals & $\mathbf{9 3 0 0 4 9 7 . 7}$ & $\mathbf{1 0 0}$ \\
\hline
\end{tabular}

Figure 1. Agriculture Sector - Type of Use

Figure 1. Agriculture Sector - Type of Use

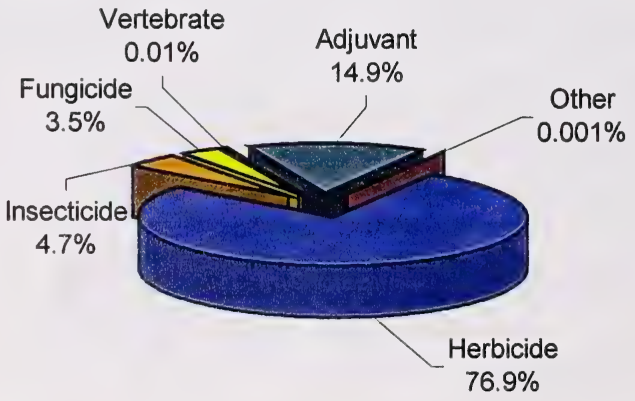


Herbicides made up the majority of pesticide use in the agricultural sector, with almost $77 \%$ of all sales. Adjuvants was the next highest category, at almost $15 \%$ of pesticide use. As discussed earlier, adjuvants and surfactants are widely used to enhance the application and effectiveness of herbicides used, and are often supplied by the manufacturer to be used in conjunction with their products. Insecticide and fungicide use were both below $5 \%$ of agricultural pesticide sales in Alberta.

In order to better compare the sector sales to Quebec sector sales, the chemical group breakdown was conducted on the agricultural pesticide sales (Table 4). The Phosphonic/Phosphinic Acids group dominated the agricultural sales at over 30\%, followed by the Phenoxy Acids group at just over $18 \%$. The Oils, Thiocarbamates and Nitro Derivatives were next at $7-8 \%$ of agricultural sales.

Table 4. Summary of Agricultural Pesticide Sales by Chemical Group

\begin{tabular}{|l|r|r|}
\hline Chemical Group & Kg ai & \multicolumn{1}{c|}{$\%$} \\
\hline Phosphonic Acids, Phosphinic Acids & 2726841.7 & 30.59 \\
\hline Phenoxy Acids & 1628866.2 & 18.27 \\
\hline Oils, Mineral and Vegetable & 767002.9 & 8.60 \\
\hline Thiocarbamates & 734218.3 & 8.24 \\
\hline Nitro Derivatives & 682990.7 & 7.66 \\
\hline Hydrocarbons & 368704.3 & 4.14 \\
\hline Carboxylic Acids & 365508.6 & 4.10 \\
\hline Benzonitriles, Nitriles & 298994.6 & 3.35 \\
\hline Organophosphorous & 263784.0 & 2.96 \\
\hline Cyclohexanedione Oximes & 187367.4 & 2.10 \\
\hline Dicarboximides, Oxathiin & 152440.3 & 1.71 \\
\hline Aryloxyphenoxyl Acids & 136306.8 & 1.53 \\
\hline Inorganics, Other & 135613.5 & 1.52 \\
\hline Alcohols & 103151.9 & 1.16 \\
\hline Dithiocarbamates & 94743.2 & 1.06 \\
\hline Organochlorines & 57159.3 & 0.64 \\
\hline Ammoniums, Quaternary & 36043.9 & 0.40 \\
\hline Sulfonylureas, Uracils & 28776.8 & 0.32 \\
\hline Pyridines & 23695.6 & 0.27 \\
\hline Miscellaneous, Non-classified & 22112.0 & 0.25 \\
\hline Azoles, Diazoles, Oxazoles, Thiazoles, Triazoles & 20110.0 & 0.23 \\
\hline Triazines, Triazinones, Tetrazines & 19098.3 & 0.21 \\
\hline Benzimadazoles, Phenylpyrroles & 18169.0 & 0.20 \\
\hline Amides, Anilines & 10111.2 & 0.11 \\
\hline Carbamates & 10076.4 & 0.11 \\
\hline Urea Derivatives & 9015.0 & 0.10 \\
\hline Fatty Acids & 4684.6 & 0.05 \\
\hline Diazines, Quinoxalines, Morpholines & 3774.9 & 0.04 \\
\hline Pyrethroids, Pyrethrins & 2497.6 & 0.03 \\
\hline
\end{tabular}




\begin{tabular}{|l|r|c|}
\hline Chemical Group & Kg ai & \% \\
\hline Amino Acids & 1091.5 & 0.01 \\
\hline Phthalic Acids & 696.3 & 0.01 \\
\hline Inorganic Coppers & 277.7 & 0.00 \\
\hline Inorganic Zincs & 44.5 & 0.00 \\
\hline Chromenones & 7.4 & 0.00 \\
\hline Organometallics & 3.8 & 0.00 \\
\hline Indanediones & 1.5 & 0.00 \\
\hline Organic Acids & 0.014 & 0.00 \\
\hline Phenols & 0 & 0.00 \\
\hline Microbials - Other than Bt & 0 & 0.00 \\
\hline Halogenated Hydrocarbons & 0 & 0.00 \\
\hline Chlorophenols & 0 & 0.00 \\
\hline Bacillus thuringiensis species & 0 & 0.00 \\
\hline \hline Totals & $\mathbf{8 9 1 3 9 8 1 . 7}$ & $\mathbf{1 0 0}$ \\
\hline
\end{tabular}

In the domestic sector (Figure 2), herbicides again dominated at just over 61\%, however insecticide sales made up a significant proportion of pesticide sales at almost $32 \%$. Fungicide sales were proportionately similar to agricultural fungicide sales, at around $5 \%$.

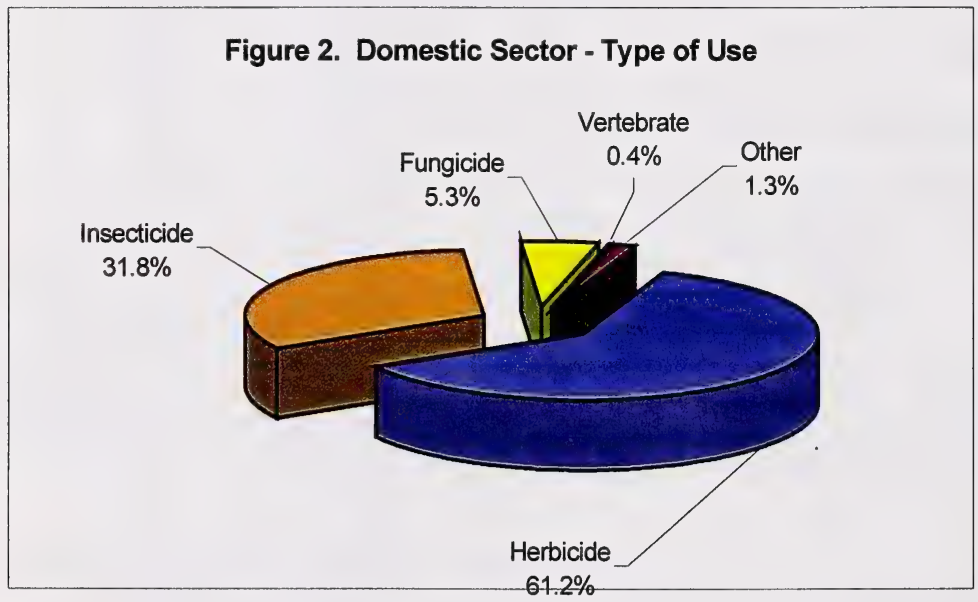

\section{Figure 2. Domestic Sector - Type of Use}

As with the agricultural products, the domestic product sales were also broken down by chemical group (Table 5) in order to compare the sales to Quebec sales figures. In the Domestic sector, the Phenoxy Acids dominated at just under $45 \%$ of total pesticide sales, followed by Inorganics and Organophosphorous, at $10 \%$. The Phosphonic/Phosphinic Acids make up a smaller proportion of domestic sales than agricultural sales, at $9.5 \%$ compared to over $30 \%$. 
Table 5. Summary of Domestic Pesticide Sales by Chemical Group

\begin{tabular}{|c|c|c|}
\hline Chemical Group & Kg ai & $\%$ \\
\hline Phenoxy Acids & 32548.89 & 44.77 \\
\hline Inorganics, Other & 7504.91 & 10.32 \\
\hline Organophosphorous & 7425.49 & 10.21 \\
\hline Phosphonic Acids, Phosphinic Acids & 6929.87 & 9.53 \\
\hline Amides, Anilines & 3972.20 & 5.46 \\
\hline Oils, Mineral and Vegetable & 3005.95 & 4.13 \\
\hline Hydrocarbons & 2782.34 & 3.83 \\
\hline Carbamates & 1457.61 & 2.00 \\
\hline Fatty Acids & 1231.60 & 1.69 \\
\hline Miscellaneous, Non-classified & 856.91 & 1.18 \\
\hline Phenols & 805.16 & 1.11 \\
\hline Carboxylic Acids & 716.07 & 0.98 \\
\hline Triazines, Triazinones, Tetrazines & 647.87 & 0.89 \\
\hline Dithiocarbamates & 563.70 & 0.78 \\
\hline Inorganic Coppers & 450.49 & 0.62 \\
\hline Phthalic Acids & 206.81 & 0.28 \\
\hline Organochlorines & 194.91 & 0.27 \\
\hline Chromenones & 168.12 & 0.23 \\
\hline Benzonitriles, Nitriles & 147.55 & 0.20 \\
\hline Pyrethroids, Pyrethrins & 128.32 & 0.18 \\
\hline Bacillus thuringiensis species & 95.00 & 0.13 \\
\hline Benzimadazoles, Phenylpyrroles & 69.71 & 0.10 \\
\hline Inorganic Zincs & 40.00 & 0.06 \\
\hline Azoles, Diazoles, Oxazoles, Thiazoles, Triazoles & 34.12 & 0.05 \\
\hline Urea Derivatives & 14.68 & 0.02 \\
\hline Diazines, Quinoxalines, Morpholines & 12.69 & 0.02 \\
\hline Pyridines & 6.33 & 0.01 \\
\hline Ammoniums, Quaternary & 3.90 & 0.01 \\
\hline Sulfonylureas, Uracils & 1.49 & 0.00 \\
\hline Nitro Derivatives & 1.23 & 0.00 \\
\hline Indanediones & 0.28 & 0.00 \\
\hline Organometallics & 0.13 & 0.00 \\
\hline Alcohols & 0.02 & 0.00 \\
\hline Aryloxyphenoxyl Acids & 0.018 & 0.00 \\
\hline Amino Acids & 0.014 & 0.00 \\
\hline Thiocarbamates & 0 & 0.00 \\
\hline Organic Acids & 0 & 0.00 \\
\hline Microbials - Other than $\mathrm{Bt}$ & 0 & 0.00 \\
\hline Imidazolinones & 0 & 0.00 \\
\hline Halogenated Hydrocarbons & 0 & 0.00 \\
\hline Dicarboximides, Oxathiin & 0 & 0.00 \\
\hline Cyclohexanedione Oximes & 0 & 0.00 \\
\hline Chlorophenols & 0 & 0.00 \\
\hline Totals & 72024.40 & 100 \\
\hline
\end{tabular}


In the Commercial/Industrial Sector, herbicides again dominated at $75 \%$ of pesticide sales (Figure 3). Insecticides made up just over $15 \%$, however this was primarily associated with high volume usage of Bacillus thuringiensis $(\mathrm{Bt})$ species for mosquito control and forest insect control operation. Fungicide sales were proportionately slightly higher in this sector, at almost $9 \%$, reflecting fungicide sales to the golf course industry.

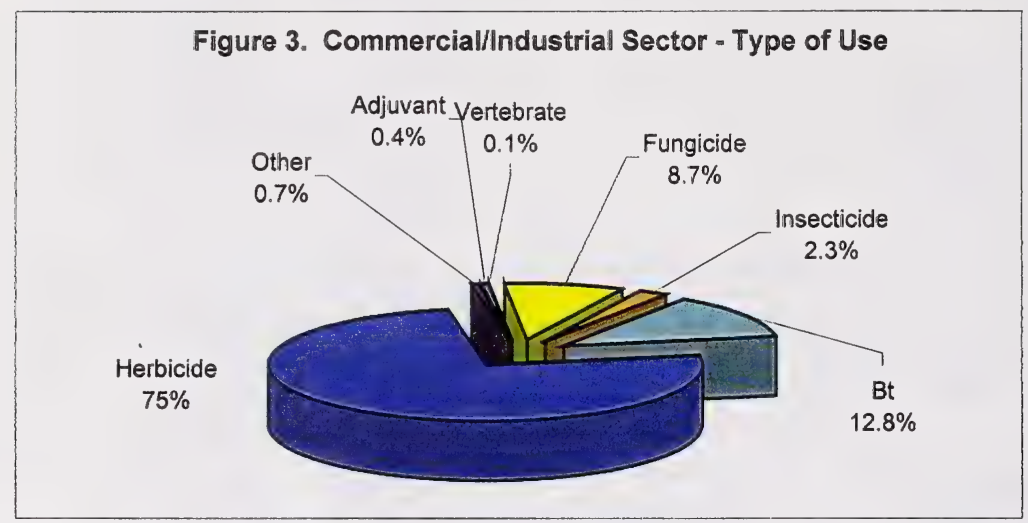

Figure 3. Commercial/Industrial Sector - Type of Use

Pesticide sales in the Livestock sector consisted of virtually all insecticides, with a small quantity of disinfectant sales also reported. The Structural sector also was dominated by insecticide sales, with a small quantity of vertebrate control products. More detailed information will be obtained when AENV conducts a use survey of the Structural sector in 2000.

\subsection{Herbicide Resistance Groups}

Herbicides from 19 groups were sold in Alberta in 1998, compared to the 28 groups that have been classified for Canada (Table 6).

Table 6. Agricultural Herbicide Sales by Resistance Grouping

\begin{tabular}{|l|r|c|}
\hline Resistance Group & \multicolumn{1}{|c|}{ Kg ai } & Percentage (\%) \\
\hline $\begin{array}{l}\text { 1. (Acetyl CoA carboxylase (ACCase) } \\
\text { inhibitors) }\end{array}$ & 323674.2 & 4.72 \\
\hline $\begin{array}{l}\text { 2 (Acetolactate synthase/aceto-hydroxyacid } \\
\text { synthase (ALS/AHAS) inhibitors) }\end{array}$ & 215185.5 & 3.14 \\
\hline 3 (Microtubule assembly inhibitors) & 682965.1 & 9.96 \\
\hline 4 (Synthetic auxins) & 1831090.2 & 26.7 \\
\hline $\begin{array}{l}5 \text { (Photosynthesis inhibitor at photosystem (PS) } \\
\text { II Site A) }\end{array}$ & 26999.0 & 0.39 \\
\hline
\end{tabular}




\begin{tabular}{|l|r|c|}
\hline Resistance Group & \multicolumn{1}{|c|}{ Kg ai } & Percentage (\%) \\
\hline $\begin{array}{l}6 \text { (Similar to Group 5, but different binding } \\
\text { behavior) }\end{array}$ & 280545.5 & 4.09 \\
\hline 7 (Photsynthesis inhibitors at PS II Site B) & 10631.0 & 0.16 \\
\hline $\begin{array}{l}8 \text { (Lipid synthesis inhibitors - not ACCase } \\
\text { inhibition) }\end{array}$ & 743743.8 & 10.85 \\
\hline 9 (EPSP* synthase inhibitors) & 2629544.5 & 38.35 \\
\hline 10 (Glutamine synthetase inhibitors) & 63400.8 & 0.92 \\
\hline $\begin{array}{l}11 \text { (Bleaching: Carotenoid biosynthesis } \\
\text { inhibitors) }\end{array}$ & 1993.2 & 0.03 \\
\hline $\begin{array}{l}14 \text { (Protoporphyrinogen oxidase (PPO) } \\
\text { inhibitors) }\end{array}$ & 26.0 & 0.0 \\
\hline 15 (Unknown) & 4710.0 & 0.07 \\
\hline 16 (Unknown) & 12559.4 & 0.18 \\
\hline 17 (Unknown) & 3.8 & 0.0 \\
\hline 19 (Indoleacetic acid action inhibitors) & 4.8 & 0.0 \\
\hline 20 (Inhibits cell wall synthesis Site A) & 577.4 & 0.1 \\
\hline 22 (Photo system I-electron diverters) & 26476.2 & 0.39 \\
\hline 23 (Mitosis inhibitors) & 679.8 & 0.01 \\
\hline 25 (Unknown) & 1091.5 & 0.02 \\
\hline Non classified Herbicides & 1598.8 & 0.02 \\
\hline Totals & 6857500.5 & 100 \\
\hline
\end{tabular}

*Enolpyruvylshikimate-3-phosphate

The sales of the amino acid biosynthesis inhibitors (Groups 2,9 and 10) made up the majority of agricultural herbicide sales in 1998 , at $42.4 \%$. These products affect amino acid synthesis, and therefore protein synthesis. Each group affects a different plant enzyme (Hall, 1996).

Sales of the auxin-like herbicides (Group 4) were next, at $26.7 \%$ of agricultural herbicide sales. This group, which is made up of phenoxy and benzoic acids, consists of some of the older and well known herbicides on the market. This group mimics the plant growth regulator indole acetic acid (auxin), and causes uncontrolled growth, resulting in unrestrained mobilization of reserves, disruption of repair mechanisms and loss of function (Hall, 1996). Auxin has several sites of action, therefore auxin herbicides act on various sites. Because of these multiple sites of action, resistance development in plants to Group 4 herbicides has been rare.

The next two groups in ranking of sales were the Group $3(9.96 \%)$ and Group $8(10.85 \%)$ herbicides, which are primarily pre-emergent wild oat herbicides. Resistance of wild oats and green foxtail to these products has developed in fields with a long history of repeated usage (AAFRD, 1998). 
The remaining herbicide groups made up less than $5 \%$ of sales, individually, and about $10 \%$ collectively.

\subsection{Geographic Distributions}

\subsubsection{Drainage Basin}

Sales of all products were broken down by drainage basin (Table 7 and Figure 4). The Oldman River basin had the highest proportion of pesticide sales, at $20.3 \%$. The Red Deer River basin was slightly behind at $18.8 \%$. The North Saskatchewan River basin was next at $15.8 \%$ of pesticide sales, followed by the Battle River basin at $13.3 \%$. The Peace River basin had just over $10 \%$ of total provincial pesticide sales, while the remaining basins were all under $10 \%$.

Pesticide use intensity by basin (Table 7 and Figure 5) is based on total pesticide sales and total (gross) basin drainage area as reported in Martin (1996) and Environment Canada (1988). The gross basin drainage overestimates the contributing area (active drainage area) within each basin, but does provide an indication of relative size. Basin use intensity is also biased by the amount of arable and/or cultivated land within the basin.

Table 7. Pesticide Sales by River Basin - Area

\begin{tabular}{|c|c|c|c|c|}
\hline River Basin & Kg ai & $(\%)$ & $\begin{array}{c}\text { Area (ha) } \\
\text { (approximate) }\end{array}$ & $\begin{array}{c}\text { Use Intensity } \\
(\mathrm{kg} / \mathrm{ha})\end{array}$ \\
\hline Milk River & 88309.0 & 0.95 & 401600 & 0.22 \\
\hline South Saskatchewan River & 526369.3 & 5.66 & 1496600 & 0.35 \\
\hline Oldman River & 1889054.3 & 20.31 & 2750800 & 0.69 \\
\hline Bow River & 708731.6 & 7.62 & 2529200 & 0.28 \\
\hline Red Deer River & 1748108.3 & 18.8 & 4678800 & 0.37 \\
\hline Sounding Creek & 126525.9 & 1.36 & 1007700 & 0.13 \\
\hline Battle River & 1238750.5 & 13.32 & 2561900 & 0.48 \\
\hline North Saskatchewan River & 1467146.3 & 15.77 & 5564000 & 0.26 \\
\hline Beaver River & 53834.8 & 0.58 & 1471500 & 0.04 \\
\hline Athabasca River & 331123.9 & 3.56 & 15862900 & 0.02 \\
\hline Peace River & 935755.7 & 10.06 & 17500000 & 0.06 \\
\hline Hay River & 27154.0 & 0.29 & 5134400 & 0.005 \\
\hline Non-specific basin & 159634.0 & 1.72 & N/A & N/A \\
\hline Alberta & 9300497.6 & 100 & & \\
\hline
\end{tabular}

The Oldman River basin had the highest relative use intensity at $0.69 \mathrm{~kg} / \mathrm{ha}$. This is the most intensively farmed area of the province, with a large proportion of cultivated land. Much of the Oldman River basin is under irrigation. The next basin in relative use is the Battle River basin, at $0.48 \mathrm{~kg} / \mathrm{ha}$. Again, the majority of this basin is under cultivation. The remaining basins have 
The remaining basins have lower relative use, ranging from $0.37 \mathrm{~kg} / \mathrm{ha}$ in the Red Deer basin down to $0.005 \mathrm{~kg} / \mathrm{ha}$ in the Hay River basin.

The use intensity in each basin is of interest for monitoring programs, as it identifies those basins which should be focussed on for monitoring programs. Another factor that helps to relate the size and scale of drainage basins and pesticide use is river discharge. A higher annual discharge in relation to overall pesticide use intensity would indicate greater potential for dilution and less pressure on the water resources in the basin. Annual flows (over various reporting periods) were obtained from Environment Canada (1993) and are listed in Table 8. The rivers with the highest discharge have the greatest dilution capacity, and other things being equal, should have lower concentrations of pesticide residues.

The highest intensity is found in the Sounding Creek basin, one of the smallest basins in Alberta. However, personal experience in sampling Sounding Creek has identified that flow of this creek is very intermittent, and the low flow is a reflection of the low precipitation in this basin (318 mm/year at Oyen -1974-1997 annual average; 207 mm/year at Esther - 1995-1998 annual average). As well, this stream originates in the prairies, and does not have the higher elevation headwaters that provide much of the base flow for the other river basins in Alberta.

Table 8. Pesticide Sales by River Basin - Flow

\begin{tabular}{|l|r|r|r|}
\hline River Basin (gauging station used) & \multicolumn{1}{|c|}{ Kg ai } & \multicolumn{1}{c|}{$\begin{array}{c}\text { Mean Annual } \\
\text { Flow (dam }\end{array}$} & Kg/dam \\
\hline Milk River (Int. Border - East crossing) & 88309.0 & 312000 & 0.283 \\
\hline South Saskatchewan River (Hwy 41) & 526369.3 & 5180000 & 0.102 \\
\hline Oldman River (at mouth) & 1889054.3 & 2190000 & 0.863 \\
\hline Bow River (near mouth) & 708731.6 & 2840000 & 0.249 \\
\hline Red Deer River (at Empress) & 1748108.3 & 2220000 & 0.787 \\
\hline Sounding Creek (at Oyen) & 126525.9 & 2170 & 58.307 \\
\hline Battle River (near Sask. border) & 1238750.5 & 227000 & 5.457 \\
\hline North Saskatchewan River (Lea Park) & 1467146.3 & 7200000 & 0.204 \\
\hline Beaver River (Cold Lake Reserve) & 53834.8 & 636000 & 0.085 \\
\hline Athabasca River (below Ft. McMurray) & 331123.9 & 20600000 & 0.016 \\
\hline Peace River (Peace Point) & 935755.7 & 66000000 & 0.014 \\
\hline Hay River (near Meander River) & 27154.0 & 2370000 & 0.115 \\
\hline Non-specific basin & 159634.0 & N/A & N/A \\
\hline Alberta & 9300497.6 & & \\
\hline
\end{tabular}

$\mathrm{Dam}^{3}=$ cubic decametre $=1000 \mathrm{~m}^{3}$ 
The next highest basin in relation to pesticide usage and average annual flow is the Battle River basin, at $5.5 \mathrm{~kg} / \mathrm{dam}^{3}$. This basin is on the north boundary of the Sounding Creek basin, and also flows through the southern and eastern portion of the Aspen Parkland and Moist Mixedgrass regions of the province, regions that experience lower levels of precipitation. As well, this is another basin that does not originate in the foothills, depending upon local snowfall and summer precipitation for primary inputs to the basin.

The other basins are all below $1 \mathrm{~kg} / \mathrm{dam}^{3}$, which are reflective of their higher annual flows. Most of the basins (the exception being the Beaver River) originate in the foothills or the Rocky Mountains, in whole or in part. The mainstems or tributaries that originate at higher elevations tend to supply a major proportion of the base flow for these basins.

\subsubsection{Pesticide Sales by Ecoregion}

Pesticide sales were also broken down by ecoregion (Figure 6) to assess pesticide sales/usage in relation to ecological regions in Alberta, which represent areas of comparable soils, climate and vegetation (Table 9). This information is of interest in relation to cropping practices that are often comparable to ecological regions, and also provide a general indicator of risk of contamination.

Pesticide sales were concentrated in five ecoregions in Alberta. The largest ecoregion (Aspen Parkland) had the greatest amount of pesticides sold, at $33 \%$ of total provincial sales. The Moist Mixed Grassland ecoregion was next at $22.6 \%$, followed by Peace Lowland/Boreal Transition at $17 \%$, the Mixed Grassland at $15.4 \%$ and the Fescue Grassland/Cypress Hills ecoregion at $9.8 \%$.

When use intensity is calculated, the Moist Mixed Grassland ecoregion has the highest use intensity at $0.67 \mathrm{~kg}$ ai/ha, followed by the Aspen Parkland and Fescue Grassland/Cypress Hills ecoregions at $0.5 \mathrm{~kg}$ ai/ha. Although the Peace Lowland/Boreal Transition ecoregion had $17 \%$ of total sales, overall use intensity was relatively low at $0.15 \mathrm{~kg}$ ai/ha. 
Table 9. Pesticide Sales by Ecoregion

\begin{tabular}{|l|r|r|r|c|}
\hline Ecoregion & Kg ai & $\mathbf{( \% )}$ & Area (ha) & $\begin{array}{c}\text { Use Intensity } \\
\text { (kg/ha) }\end{array}$ \\
\hline Aspen Parkland & 3073153.0 & 33.04 & 5901232 & 0.52 \\
\hline Moist Mixed Grassland & 2101336.7 & 22.59 & 3157121 & 0.67 \\
\hline $\begin{array}{l}\text { Peace Lowland/Boreal } \\
\text { Transition }\end{array}$ & 1585861.3 & 17.05 & 10376038 & 0.15 \\
\hline Mixed Grassland & 1432542.1 & 15.4 & 4660407 & 0.31 \\
\hline $\begin{array}{l}\text { Fescue Grasslands, Cypress } \\
\text { Hills }\end{array}$ & 913942.6 & 9.83 & 1815757 & 0.50 \\
\hline Non specific ecoregion & 159634.0 & 1.72 & & N/A \\
\hline Mixed Boreal Upland & 31459.1 & 0.34 & 22568703 & N/A \\
\hline Western Alberta Uplands & 2100.8 & 0.02 & 9042489 & 0.001 \\
\hline Subalpine and Alpine & 468.2 & 0.01 & 4741074 & 0 \\
\hline Northern Alberta Uplands & 0 & 0.0 & 2396502 & 0 \\
\hline Athabasca Plains & 0 & 0.0 & 1254078 & 0 \\
\hline Alberta & $\mathbf{9 3 0 0 4 9 7 . 8}$ & $\mathbf{1 0 0}$ & & \\
\hline
\end{tabular}

\subsubsection{Pesticide Sales by Municipality, AENV and AAFRD Regions}

Pesticide sales were broken out by rural municipality to provide a detailed geo-administrative overview of sales, using municipal boundaries that are familiar to many individuals and various levels of government. The largest volume of sales $(>500,000 \mathrm{~kg}$ ai) occurred in the County of Lethbridge and the MD of Taber, which are major supply and distribution centres for southern Alberta, particularly the irrigated region of Alberta. Municipalities with greater than $300000 \mathrm{~kg}$ ai of sales were the Counties of Vulcan, Vermilion River, Red Deer and Wheatland. These are large municipalities containing the highest proportion of total crop area in Alberta (AAFRD 1999c), with intensive agricultural production. Data on primary crops grown in 1996 in the six municipalities with highest sales was derived from AAFRD (1999c)(Table 10). Acreages for major crop groups varied between municipality, however cereals (primarily wheat) dominated in each municipality. Oilseeds (primarily canola) had relatively high acreage in Vermilion River and Wheatland, but relatively low acreage in Taber and Lethbridge. Potatoes and sugar beets accounted for most of the Other Field Crops grown in Taber and Lethbridge, while field peas were extensively grown in Vermilion River. Vegetable production was predominately in the irrigated municipalities of Taber and Lethbridge. The range of crop types in various municipalities influences the type of pesticides used, as well as the use intensity (rate and frequency of application). Potatoes and sugar beets use very different products than cereals and oilseeds, and pesticide use is often more intensive on these types of crops for disease suppression, weed control and insect control. This is reflected in the use intensities for Taber and Lethbridge, 
which are relatively high at over $2.5 \mathrm{~kg} / \mathrm{ha}$. These municipalities may also serve as regional supply centres, so the use intensities for these two may be a slight overestimation.

Table 10. Crop Groups Grown in High Pesticide Sales Municipalities (hectares), With Agricultural Sales (kg ai) and Use Intensity (kg ai/ha)

\begin{tabular}{|l|c|c|c|c|c|c|}
\hline Crop Group & Taber & Lethbridge & Wheatland & Red Deer & Vulcan & $\begin{array}{c}\text { Vermilion } \\
\text { River }\end{array}$ \\
\hline $\begin{array}{l}\text { Cereals (Wheat, oats, } \\
\text { barley, etc }\end{array}$ & 134925 & 171178 & 217077 & 152870 & 212613 & 214977 \\
\hline $\begin{array}{l}\text { Oilseeds (Canola, } \\
\text { flaxseed, mustard) }\end{array}$ & 14929 & 24609 & 44596 & 19082 & 35789 & 55043 \\
\hline $\begin{array}{l}\text { Other Field Crops } \\
\text { (Potatoes, Peas, Sugar } \\
\text { Beets, etc) }\end{array}$ & 22937 & 9210 & 2167 & 3529 & 2182 & 6879 \\
\hline $\begin{array}{l}\text { Vegetables (Sweet } \\
\text { corn, etc) }\end{array}$ & 3337 & 367 & 17 & 39 & 1 & 18 \\
\hline Hay and Forage & 18729 & 19626 & 19228 & 63836 & 10587 & 23015 \\
\hline Total Hectares & 194857 & 224990 & 283085 & 239356 & 261172 & 299932 \\
\hline Kg ai & 519053.3 & 562955.4 & 385152.6 & 306547.0 & 315699.7 & 358663.4 \\
\hline Kg/ha & 2.66 & 2.50 & 1.36 & 1.28 & 1.21 & 1.20 \\
\hline
\end{tabular}

Sales for all of the municipalities are summarized in Table 11. Some municipalities that have very low sales may not be indicative of pesticide use in that municipality, as there are few, if any, vendors in those municipalities. However there is some agricultural production in those municipalities (i.e., Acadia, Brazeau, Ranchland, Saddle Hills), and pesticide products would have been brought in from surrounding municipalities that had vendors. Pesticides sold in the National Parks were primarily lawn and garden products. A graphical depiction of pesticide sales with municipal boundaries is given in Figure 7.

Table 11. Pesticide Sales by Municipality

\begin{tabular}{|l|c|l|c|l|r|}
\hline Municipality & Kg ai & Municipality & Kg ai & Municipality & Kg ai \\
\hline Lethbridge & 570878.8 & Westlock & 143180.8 & Peace & 58279.8 \\
\hline Taber & 522806.6 & Minburn & 141406.7 & Northern Lights & 51926.2 \\
\hline Wheatland & 387109.3 & Wainwright & 141197.6 & Special Area 4 & 45332.1 \\
\hline Vermilion River & 359674.3 & Lamont & 131521.7 & Athabasca & 44166.0 \\
\hline Vulcan & 315876.0 & Mackenzie & 124406.7 & Big Lakes & 43168.1 \\
\hline Red Deer & 314630.4 & Lacombe & 118789.9 & Bonnyville & 41444.3 \\
\hline Flagstaff & 290548.4 & Strathcona & 114132.2 & Clear Hills & 37845.0 \\
\hline Camrose & 260686.0 & Two Hills & 111359.3 & Special Area 2 & 36551.3 \\
\hline Rocky View & 256804.4 & Leduc & 109722.0 & Edmonton & 34814.4 \\
\hline
\end{tabular}




\begin{tabular}{|l|r|l|r|l|r|}
\hline Municipality & Kg ai & Municipality & Kg ai & Municipality & Kg ai \\
\hline Kneehill & 256784.1 & Starland & 108328.4 & Woodlands & 29970.6 \\
\hline Forty Mile & 255335.6 & Spirit River & 104149.2 & Thorhild & 23649.6 \\
\hline Willow Creek & 246542.7 & Stettler & 103858.6 & Lesser Slave River & 4981.2 \\
\hline Cypress & 218076.2 & Fairview & 101475.1 & Clearwater & 4179.7 \\
\hline Drumheller & 192238.1 & Provost & 96377.5 & Greenview & 2336.9 \\
\hline Mountain View & 188243.0 & Wetaskiwin & 94913.1 & Yellowhead & 1836.6 \\
\hline Grande Prairie & 186631.1 & St. Paul & 85724.8 & Wood Buffalo & 951.9 \\
\hline Foothills & 173380.4 & Calgary & 84674.6 & Lakeland & 742.9 \\
\hline Special Area 3 & 173253.4 & Parkland & 81230.0 & Ranchland & 260.7 \\
\hline Warner & 170810.8 & Ponoka & 80699.9 & Lac Ste. Anne & 234.6 \\
\hline Beaver & 170563.0 & Smoky Lake & 80099.7 & Brazeau & 156.6 \\
\hline Newell & 169097.3 & Paintearth & 76647.8 & Bighorn & 96.0 \\
\hline Cardston & 167378.6 & Birch Hills & 73976.6 & National parks & 55.4 \\
\hline Sturgeon & 167109.9 & Barrhead & 69543.8 & Saddle Hills & 32.6 \\
\hline Alberta (non specific) & 159634.0 & Pincher Creek & 64125.7 & Opportunity & 0.2 \\
\hline Smoky River & 159489.5 & East Peace & 62361.0 & Acadia & 0 \\
\hline & & & & Total & 9300497.3 \\
\hline
\end{tabular}

Pesticide sales were also broken down by Alberta Environment (AENV) regions (Figure 8), primarily to identify relative usage for program planning and resource deployment for pesticide regulatory programs (Table 12). The regions with the highest quantity of sales were Parkland and Prairie regions, at over $2.5 \mathrm{M} \mathrm{kg}$ ai, followed by the Bow Region at just under $1.9 \mathrm{M} \mathrm{kg}$ ai. The region with the smallest sales volume was the North East Slopes region at just over $326000 \mathrm{~kg}$ ai.

Table 12. Pesticide Sales by AENV Region

\begin{tabular}{|l|r|}
\hline AENV Region & Sales (kg ai) \\
\hline Parkland & 2795198.2 \\
\hline Prairie & 2532091.8 \\
\hline Bow & 1883670.4 \\
\hline Northwest Boreal & 1010950.4 \\
\hline Northeast Boreal & 592825.1 \\
\hline Northeast Slopes & 326137.6 \\
\hline Alberta (non-specific) & 159634.0 \\
\hline Total & $\mathbf{9 3 0 0 5 0 7 . 5}$ \\
\hline
\end{tabular}

Agricultural pesticide sales were also broken out by Alberta Agriculture, Food and Rural Development regions (Figure 8), for use in program planning (Table 13). Highest sales were in the Southern region at over $3.2 \mathrm{M} \mathrm{kg}$ ai, followed by the Northern region at $2.7 \mathrm{M} \mathrm{kg}$ ai. The Peace region was the lowest in agricultural pesticide sales, at just under $1 \mathrm{M} \mathrm{kg}$ ai. 
Table 13. Agricultural Pesticide Sales by AAFRD Region

\begin{tabular}{|l|r|}
\hline AAFRD Region & Sales (kg ai) \\
\hline Southern & 3225351.0 \\
\hline Northern & 2734174.2 \\
\hline Central & 1977926.2 \\
\hline Peace & 967122.0 \\
\hline Alberta (non-specific) & 9417.8 \\
\hline Total & $\mathbf{8 9 1 3 9 9 1 . 2}$ \\
\hline
\end{tabular}

\subsubsection{Pesticide Sales by Irrigation District}

Pesticide sales were broken down by irrigation district to give an indication of the intensity of pesticide use in the irrigated areas of Alberta. As discussed earlier, the irrigation districts may or may not have vendors located within their boundaries (Figure 9), therefore the sales and usage linkage assumption in this case is not strong. Information on total acreage of crops grown in the irrigation districts, and acreage under irrigation in 1998 was obtained from AAFRD (1999b), and are also listed in Table 14.

Table 14. Pesticide Sales by Irrigation District

\begin{tabular}{|l|r|r|r|}
\hline Irrigation District & Kg ai & Acres Irrigated & $\begin{array}{c}\text { Total Assessed } \\
\text { Acres }\end{array}$ \\
\hline Mountain View & 0 & 1053 & 3722 \\
\hline Leavitt & 42712.6 & 4600 & 4769 \\
\hline Aetna & 0 & 1930 & 3519 \\
\hline United & 0.2 & 17276 & 34353 \\
\hline Magrath & 124665.8 & 11189 & 18300 \\
\hline Raymond & 25080.1 & 32259 & 45533 \\
\hline Lethbridge Northern & 453922.6 & 122379 & 153365 \\
\hline Taber & 255669.8 & 76872 & 80455 \\
\hline St. Mary River & 411681.6 & 342758 & 360780 \\
\hline Ross Creek & 39253.3 & 1055 & 1210 \\
\hline Bow River & 201109.0 & 198197 & 210690 \\
\hline Western & 298181.1 & 67643 & 86771 \\
\hline Eastern & 169097.3 & 274942 & 280573 \\
\hline Totals & $\mathbf{2 0 2 1 3 7 3 . 4}$ & $\mathbf{1 1 5 2 1 5 3}$ & $\mathbf{1 2 8 4 0 4 0}$ \\
\hline
\end{tabular}

The table shows that there is not a very good correlation between $\mathrm{kg}$ ai sold and the area farmed (assessed) or irrigated. For example, only $0.2 \mathrm{~kg}$ of pesticide sales could be attributed directly to the United irrigation district, yet over 34000 acres were farmed. On the other hand, almost 300 $000 \mathrm{~kg}$ ai of pesticide sales were attributed to vendors within the Western irrigation district, yet just over 86000 acres were farmed. Because of the relatively small sizes of the irrigation districts 
in relation to the size of trading areas associated with some vendors, the direct association between sales and acreage farmed (with or without irrigation) in the irrigation districts is not possible. Detailed pesticide use data would be required to delineate pesticide use under irrigation. 

Figure 4. Total Pesticide Sales By River Basin ('000 kg ai) - 1998

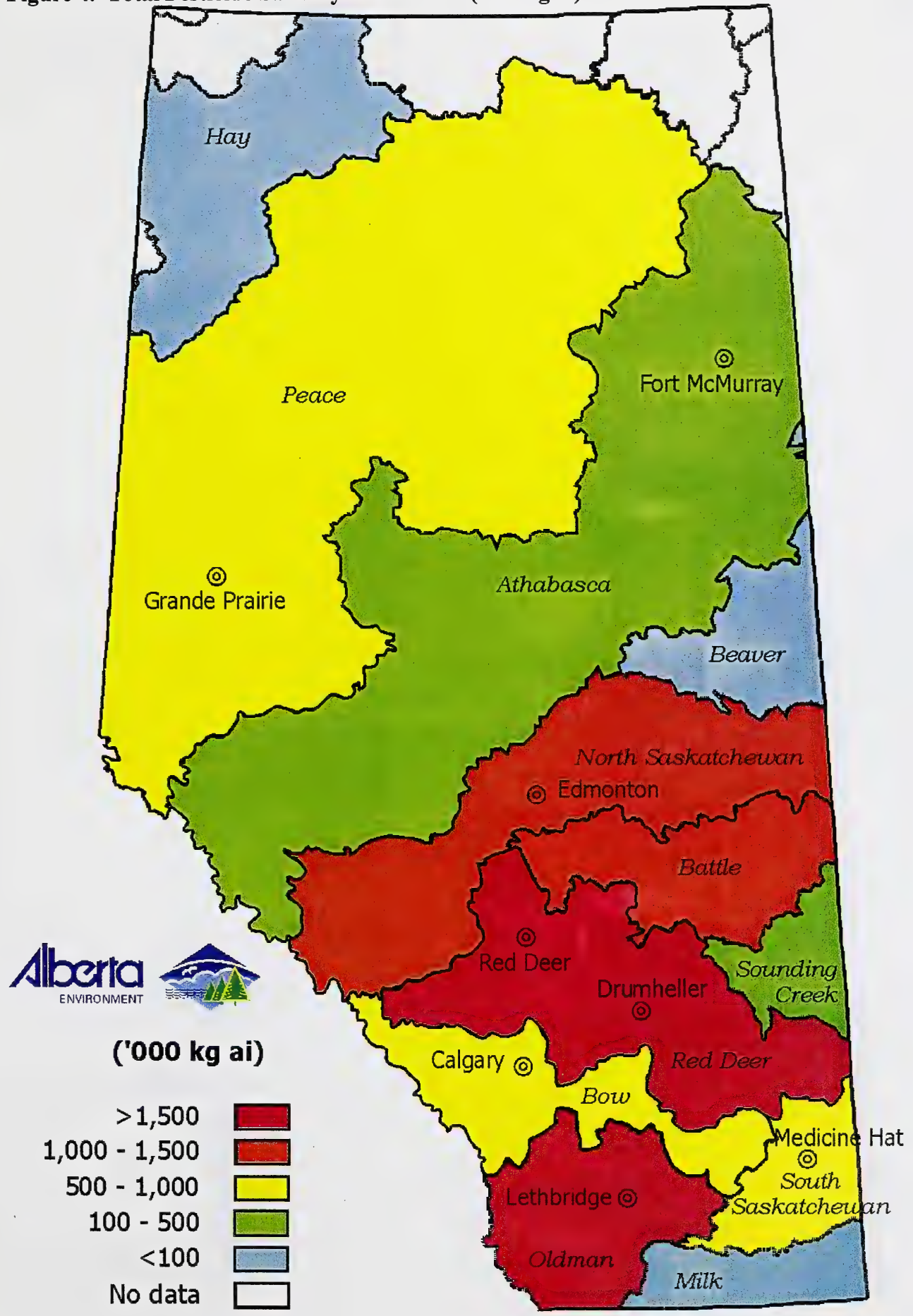



Figure 5. Estimated Pesticide Use Intensity by River Basin (kg ai/ha) - 1998

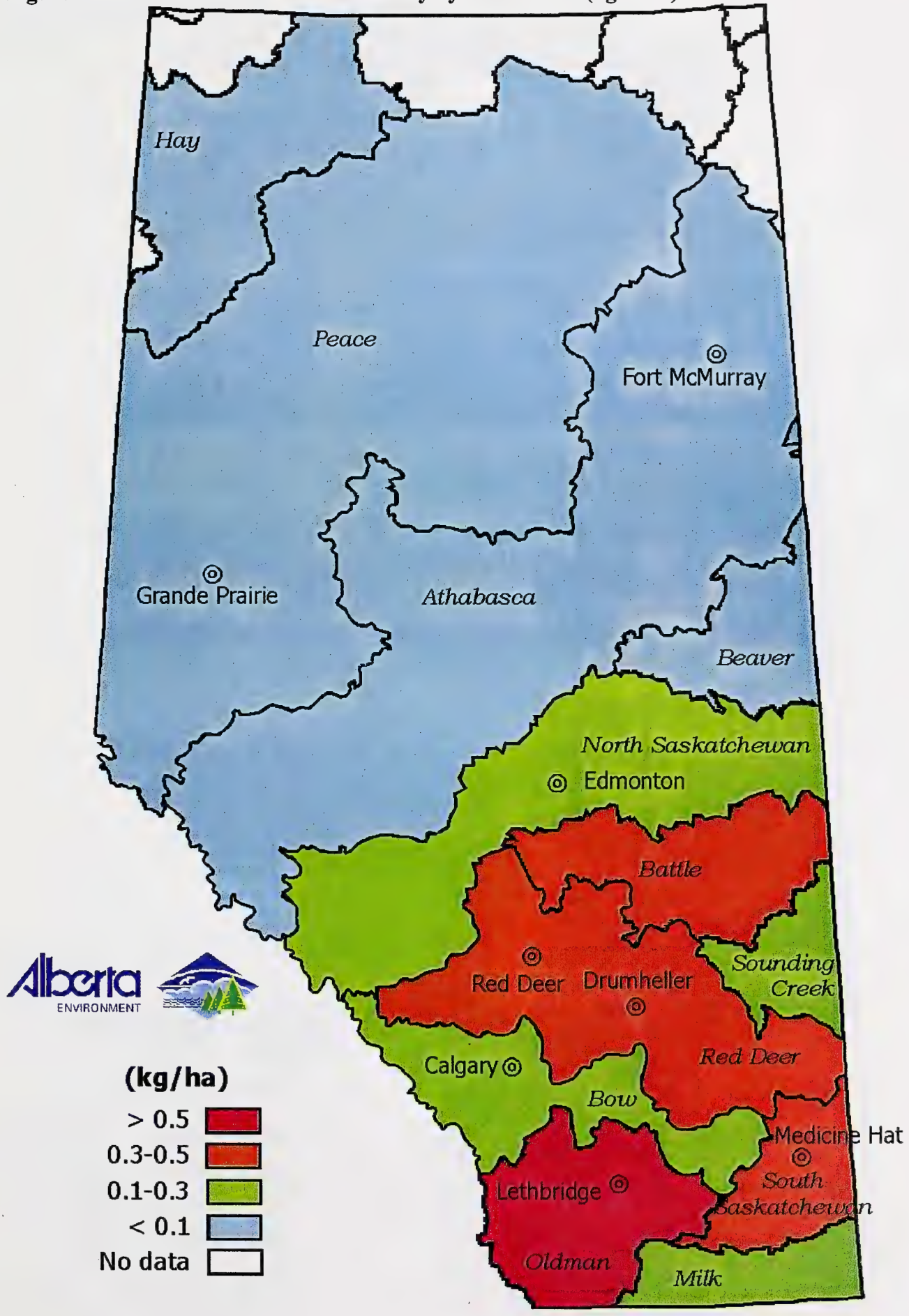



Figure 6. Total Pesticide Sales by EcoRegion ('000 kg ai) - 1998

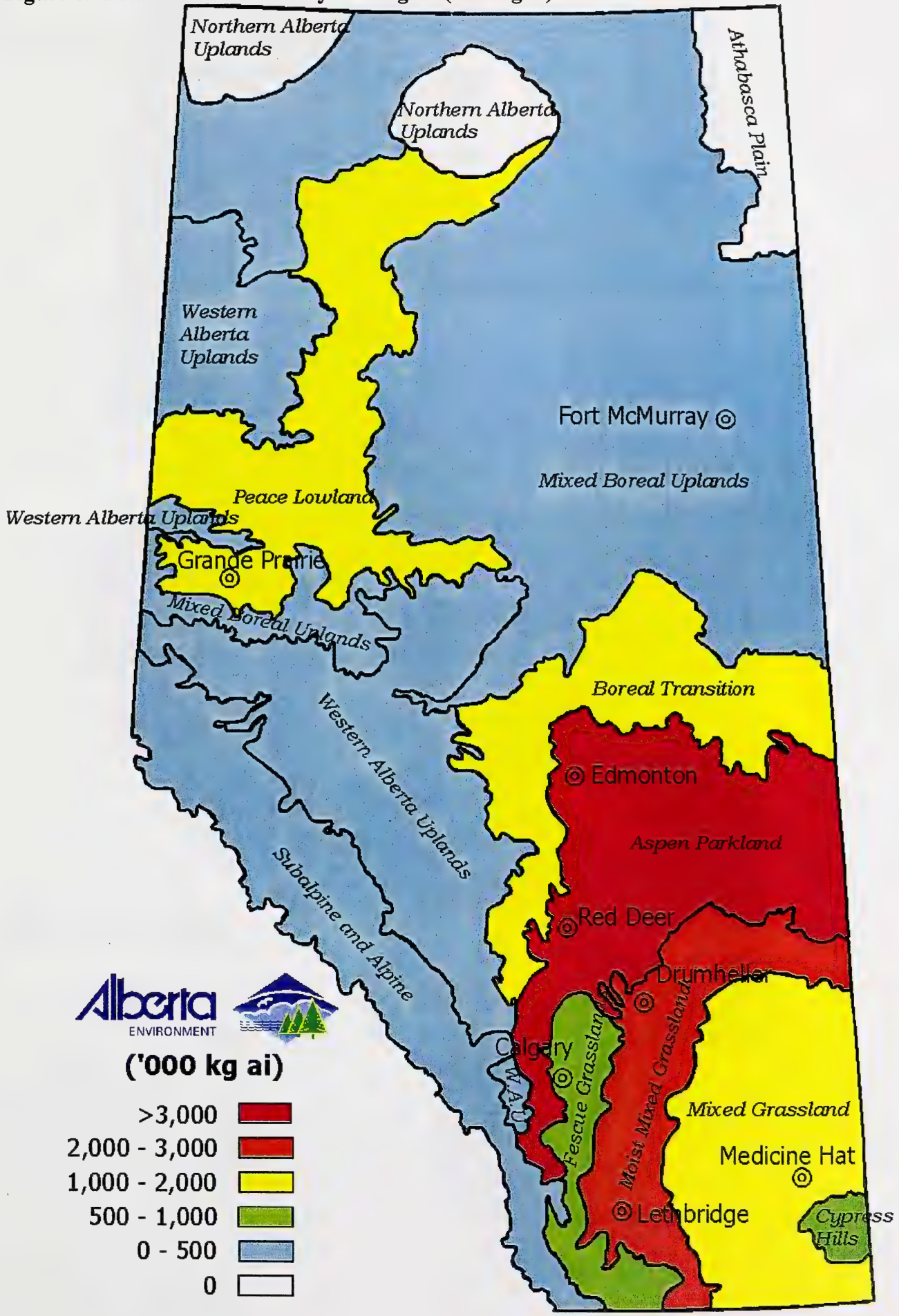



Figure 7. Total Pesticide Sales by Municipality ('000 kg ai) - 1998

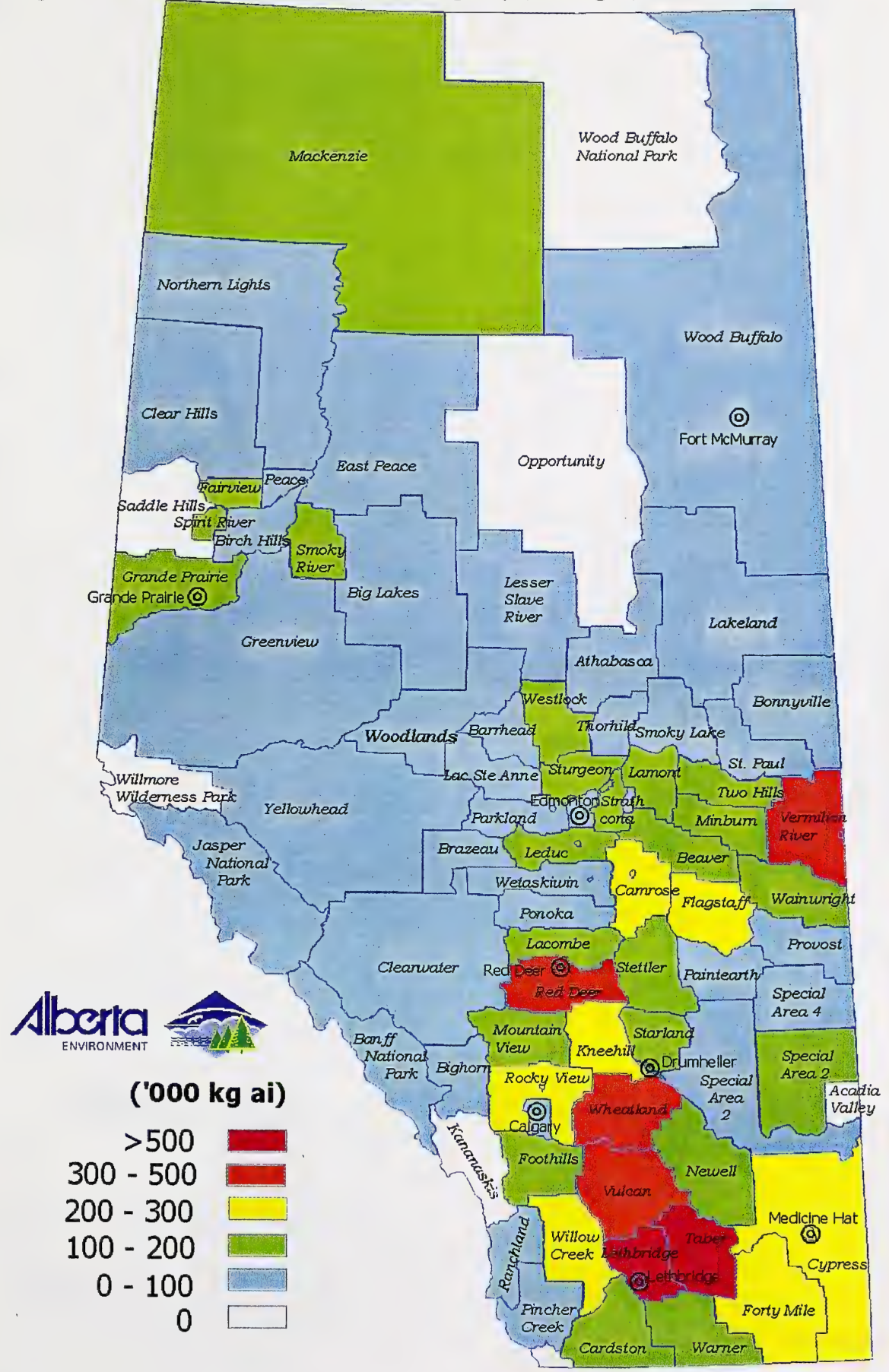



Figure 8. Alberta Government Regions

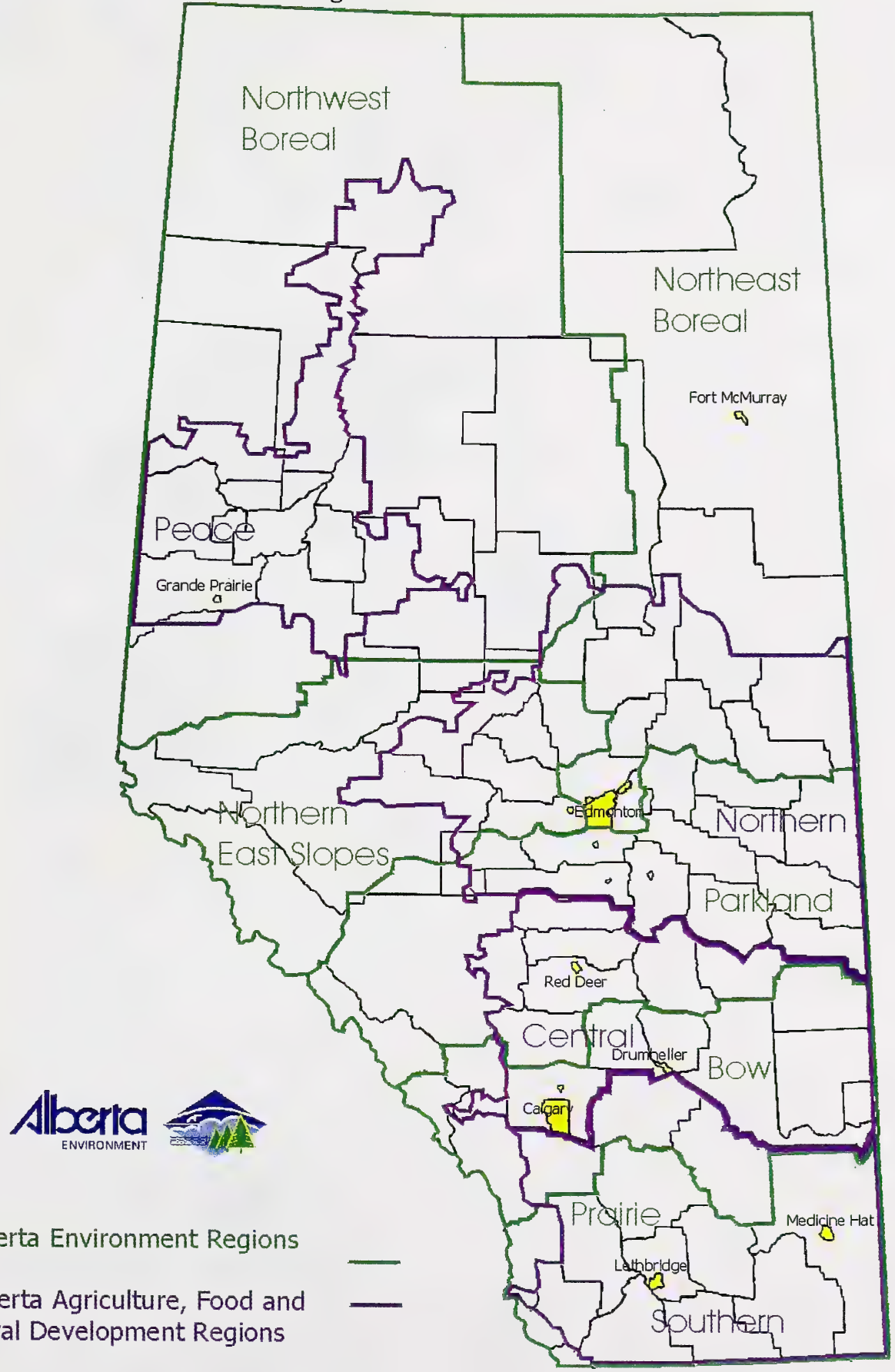



Figure 9. Irrigation Districts in Alberta

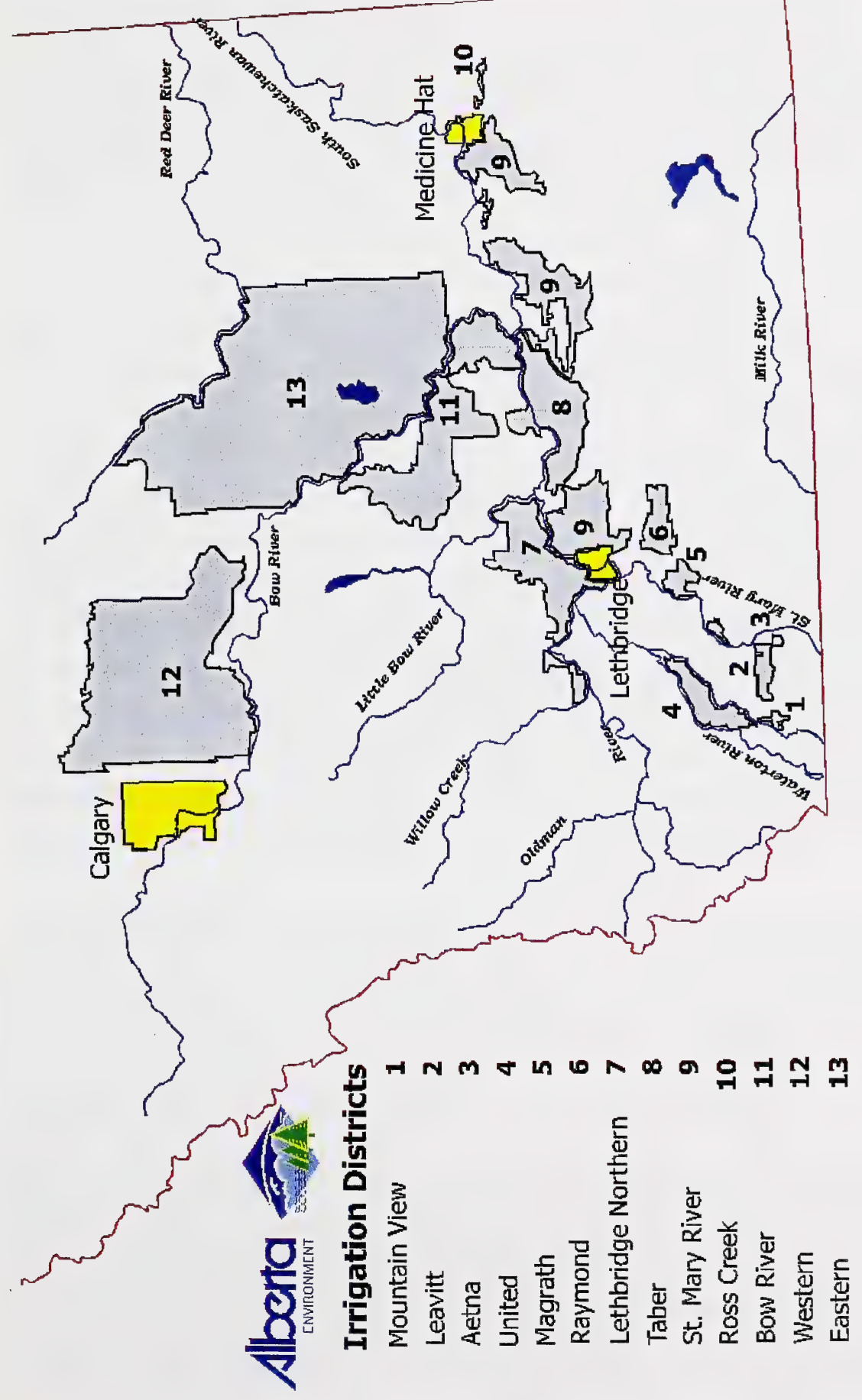





\subsection{Discussion}

\subsection{Use Intensity}

One of the measurements used to compare relative pesticide use between different geographic areas is use intensity, usually measured as $\mathrm{kg}$ ai/ha. Using 1993 agricultural pesticide sales data, and adjusting the data to compensate for the proportion of sales data obtained in that year, it was estimated that pesticide use intensity in Alberta was $0.8 \mathrm{~kg}$ ai/ha (AENV 1998). Using a more comprehensive data set from 1998, total agricultural pesticide sales of $8913982 \mathrm{~kg}$ was divided by the 1996 total cropland in Alberta (9 546886 ha - AAFRD 1999c) to arrive at a pesticide use intensity of $0.93 \mathrm{~kg}$ ai/ha. However, data on sales of adjuvant was not collected in 1993, and a more accurate comparison was obtained by removing that component from the agricultural sales of 1998 (1 $325320 \mathrm{~kg}$ ), which resulted in a revised use intensity of $0.79 \mathrm{~kg}$ ai/ha. The 1993 use intensity value was an estimation (a conscious over-estimate to compensate for the limited data available), and the similarity between pesticide use intensity in 1993 and 1998 on its own does not indicate that pesticide use remained unchanged from 1993 to 1998. In fact, other information on national pesticide sales from 1994 to 1998 (\$1.0 to \$1.4 billion - CPI 2000) and recovery of pesticide containers collected in Alberta (736 225 in 1993 to 1.2 M containers in 1998 - Curtis Construction - annual summaries) suggests that pesticide use has increased over the five years. However this apparent trend could be due to replacement of lower cost pesticides with higher cost pesticides, and replacement of products sold in bulk or refillable containers with products sold in non-refillable containers. Subsequent pesticide sales surveys may improve the ability to detect trends in pesticide use intensity in Alberta.

Within Alberta, highest agricultural use intensities were reported for the rural municipalities of Taber and Lethbridge. This is related to the intensive agricultural production undertaken in these municipalities and relatively large acreages of specialty crops under irrigation. Part of the reason for the high use intensities could be related to the fact that these municipalities (esp. Lethbridge) may have vendors that serve a larger area than the immediate municipality.

However, when compared to other regions, Alberta's overall pesticide use intensity at $0.79 \mathrm{~kg} / \mathrm{ha}$ is at the lower end of the spectrum. Although total pesticide sales in Quebec are substantially lower than in Alberta, pesticide use intensity was much higher (3.2 kg/ha in 1997 - Gorse 1999). This was predominately due to high application rates $(3 \mathrm{~kg} / \mathrm{ha})$ on their large acreage crops (corn and soybean), and even higher rates on specialty crops like potatoes, tobacco and apples. Overall, 
pesticide use in Quebec has declined over recent years, and agricultural pesticide use intensity has declined from $3.8 \mathrm{~kg} / \mathrm{ha}$ in 1993 to $3.2 \mathrm{~kg} / \mathrm{ha}$ in 1997 (Gorse 1999).

Other regions report even higher use intensity rates. The agricultural use intensity in the US in 1997 was estimated to be $2.8 \mathrm{~kg} / \mathrm{ha}$ (EPA 1999), European use intensity ranges from $4-6 \mathrm{~kg} / \mathrm{ha}$, Japan is at $7.7 \mathrm{~kg} / \mathrm{ha}$ (AENV 1998), and California agricultural use intensity was calculated to be $24.9 \mathrm{~kg} / \mathrm{ha}$ (USDA 2000, CDPR 1999).

\subsection{Pesticide Sales Data for Quebec}

Because Quebec is the only other province to publish recent detailed sales information, comparison with Alberta sales data can be undertaken. Quebec's agricultural pesticide use showed a different range of products sold, which relates to the primary crops planted in Quebec (corn and soybean), compared to wheat, barley and canola here in Alberta. Agricultural sales in Quebec were substantially lower at $2732751 \mathrm{~kg}$ ai (Gorse, 1999), compared to almost $9 \mathrm{M}$ kg ai in Alberta. The Amides group dominated agricultural sales in Quebec at $18.5 \%$, compared to Alberta Amides, Aniline sales at $0.11 \%$. The Triazines were the next largest group in Quebec at $15.8 \%$, compared to Alberta at $0.21 \%$. Products from these groups are primarily used on corn and soybean, of which very little acreage occurs in Alberta. Following the Triazines were the Dithiocarbamates at $10.5 \%$, then the Oils, Mineral and Vegetable at $10.4 \%$. On the other hand, Alberta has high acreages of cereals and canola, for which Phosphonic/Phosphinic Acids and Phenoxy Acids are primarily used on. The pre-emergent herbicides (Thiocarbamates and Nitro Derivatives) are also extensively used in cereal production, more than for corn or soybeans.

Their smaller acreage in crops (848 $201 \mathrm{ha}$ ) compared to Alberta's cropped acreage of 9546886 ha is also reflected in their much lower agricultural sales (2 $732751 \mathrm{~kg}$ vs $8913982 \mathrm{~kg}$ ), even with a higher use intensity.

A comparison of domestic sales data highlights some important differences. In Alberta, phenoxy herbicides were the biggest component of domestic sales, with over half (61.6\%) of the phenoxy acids (2,4-D and mecoprop mainly) originating from weed and feed formulations sold in granular or liquid form. Quebec does not collect sales data on weed and feed formulations, while the remaining phenoxy herbicide sales data made up a small quantity of domestic sales (15 $908 \mathrm{~kg}$ ai $-5.5 \%$ )(Gorse 1999). On the other hand, their Ornamental Horticulture sector, which includes lawncare companies, municipal governments, golf courses and other related facilities, had 
phenoxy herbicide sales of over $72000 \mathrm{~kg}, 71 \%$ of pesticide sales to this sector. It would appear from the sales data that in Quebec, a large proportion of lawn weed control is conducted by commercial lawn care companies. On the other hand, the lack of sales data on weed and feed formulations may actually underestimate the homeowners use of phenoxy herbicides. In both provinces, phenoxy herbicides are likely the most used herbicides in the domestic sector, even though this may not be apparent in a cursory comparison of sales data.

Sales of domestic insecticides were also markedly different in Quebec and Alberta. Domestic pesticide sales were higher in Quebec (289 $127 \mathrm{~kg}$ ai) (Gorse, 1999) than in Alberta. The majority of products sold in Quebec were Hydrocarbons, at $49.9 \%$, compared to Alberta at just $3.8 \%$. The next largest group sold in Quebec was the Organochlorines, at $24.3 \%$, compared to Alberta at $0.27 \%$. Mothball products from these two groups made up $82 \%$ of domestic insecticide sales (Gorse 1999). Incomplete sales data was obtained from domestic product suppliers in Alberta on mothballs.

In Alberta, the Organophosphates were the largest insecticide group at $7425 \mathrm{~kg}$ ai, compared to $3166 \mathrm{~kg}$ ai for the comparable chemical group in Quebec. Given that Quebec has a much larger urban population than Alberta, this suggests that commercial operations provide the bulk of insect control in Quebec, or that Alberta has greater lawn and garden insect problems than Quebec, or that Quebec residents have a greater tolerance to lawn and garden insects.

The comparison of sales data between Quebec and Alberta illustrates the difficulty in making objective, accurate comparisons because of different crops (resulting in different products being used), different climatic conditions, and different ways of assembling and reporting information. These difficulties would apply to comparisons among Canadian provinces, as well as between Alberta and other countries.

\subsection{Herbicide Tolerant Canola}

The advent of herbicide tolerant canola (HTC) (Roundup Ready canola, Liberty Link canola, Pursuit Smart canola, etc) during the 1990's has changed crop production practices and pesticide use substantially. Estimated acreage of herbicide tolerant canola seeded in Alberta in 1998 was 1073871 ha (Thomas 2000, Canola Council 2000). Comparing 1993 to 1998 sales for the herbicide products associated with HTC (Roundup, Liberty and Pursuit) is difficult, as the Prairie versions of Liberty and Pursuit were only registered in 1995. Roundup, however, has been 
registered for a number of years, and comparing the Phosphonic/Phosphinic Acid sales for 1993 (adjusted) and 1998 (actual) shows a 162\% increase in sales for this group over the five years. Part of this increase can be attributed to label expansions for these products (pre-harvest application with Roundup being the primary expansion), but a portion of the increase can be attributed to the HTC acreage. Overall canola acreage in Alberta increased 21\% between 1993 and 1998 (Canola Council 2000).

\subsection{Herbicide Resistance}

Resistance to herbicides is a function of repeated use of herbicides from the same group and resistance susceptible weeds. In Western Canada, large numbers of sites with confirmed weed resistance have been reported for Groups 1, 2, 3 and 8 (Hall et al. 1999).

The Group 1, 3 and 8 compounds have been used in Alberta for many years, primarily for wild oat control. Repeated use of some of these compounds (especially triallate - Group 8) has led to an extensive number of sites with established wild oat resistance. The Group 9 products, at almost $11 \%$ of agricultural herbicide sales, are still relatively widely used in Alberta. The Group 3 compounds (ethalfluralin and trifluralin primarily) are still widely used, at almost $10 \%$ of herbicide sales and have a large number of reported sites with green foxtail resistance in Alberta (Hall et al. 1999). The Group 1 herbicides ('fops and 'dims) also have a large number of sites in Western Canada with reported weed resistance for wild oats and green foxtail. Although the use of Group 1 herbicides is about half that of Group 3's or Group 8's, resistance as an issue with Group 1's is nearly as important as in the other groups.

However, the level of use alone is not a major factor in assessing the potential for herbicide resistance. For example, no resistance has been reported for Group 9 and 10 herbicides in Western Canada (Hall et al. 1999). Resistance to Group 9 herbicides has been reported from Australia (Heap, 1997) and given the extensive use (over $38 \%$ of herbicides) of Group 9 herbicides in Alberta (wide acreage sprayed and multiple annual applications in some cases), the potential for development of Group 9 resistance in Alberta is a concern to the agricultural industry. The Group 2 herbicides (sulfonylurea's and imidazolinones) have extensive resistance development in Alberta, particularly for chickweed, with greater than 200 sites in Western Canada with reported weed resistance (Hall et al. 1999). The sulfonylurea's are applied at extremely low rates (3-15 g ai/acre, Cotton and Byrtus 1995), which, by sales volume alone, underrepresents the potential for these products to develop weed resistance. The Group 4 
herbicides, at almost $27 \%$ of agricultural herbicide sales, have only one site in Western Canada with reported weed resistance (Hall et al. 1999).

The use of pesticide sales data in relation to herbicide resistance is best utilized when trends can be discerned. In 1988-1993, trends in several pesticides were observed to be decreasing in sales (triallate, trifluralin and difenzoquat), while ethalfluralin was increasing. Comparing the Group 3 herbicides sold in 1993 (751 $834 \mathrm{~kg}$ ai) to the Group 3 herbicides sold in 1998 (682 $965 \mathrm{~kg} \mathrm{ai}$ ), shows a decrease, especially as the sales data from 1998 is much more comprehensive. Sales of Group 8 herbicides in 1993 (452 $889 \mathrm{~kg}$ ai) compared to 1998 sales (734 $744 \mathrm{~kg}$ ai) would appear to be increasing. Given that sales reported in 1993 were estimated to be approximately $1 / 2$ of actual sales (Cotton and Byrtus 1995), a doubling of 1993 sales to $905778 \mathrm{~kg}$ ai would suggest that sales of Group 8 herbicides in 1998 have also decreased, albeit not as much as the Group 3 herbicides.

\subsection{Drainage}

Highest overall sales of pesticides was in the Oldman River basin, however highest use relative to annual basin flow was found to be in the Sounding Creek and Battle River basins. This information has implications for defining priorities in existing and future monitoring programs. For example, there is only one stream site currently being sampled on a long-term, regular basis in the Sounding Creek basin, and only two sites in the Battle River basin. Intermittent flows of the Sounding Creek further limit the monitoring data available for this basin.

On the other hand, a basin like the Oldman River has a number of long-term monitoring sites that include pesticide analysis, and a current large scale monitoring program for the basin has added a number of additional sites that include samples for pesticide analysis. The number of sites sampled in any one basin reflects the importance of the water to agricultural, industrial and residential development, rather than the perceived risk of pesticide contamination. 


\subsection{Conclusions}

This overview of pesticide sales data collected for 1998 provides a general framework for pesticide program review and comparisons to other regions, however more detailed analysis of the data will be required for utilization in monitoring program development in Alberta. This overview will also provide the information to better base decisions on future regulatory changes. Future surveys of pesticide sales in Alberta will assist in keeping pesticide use in perspective and measuring overall use trends.

Key results of the 1998 survey are:

- Total sales volume was just over $9.3 \mathrm{M} \mathrm{kg}$ of active ingredient.

- Herbicides and plant growth regulators made up $76.7 \%$ of the total sold.

- Of the chemical groups, the Phosphonic/Phosphinic Acid group had the highest sales, comprising $29.9 \%$ of total pesticide sales.

- The Agriculture sector accounted for $95.8 \%$ of all pesticides sold in Alberta, with $76.9 \%$ of that being herbicides, and $4.7 \%$ being insecticides. The insecticide sales volume was relatively high for Alberta, as 1998 was an outbreak year for Lygus bug.

- The Domestic sector accounted for $0.8 \%$ of total pesticide sales, with herbicides making up $61.2 \%$ and insecticides $31.8 \%$.

- Of the herbicide resistance groups, the Group 4 and Group 9 herbicides made up the largest proportion of sales at $26.7 \%$ and $38.35 \%$, respectively.

- Spatially, the Oldman River and Red Deer River basins had the largest quantities of sales by river basin at over $1.7 \mathrm{M} \mathrm{kg}$ ai, while the Oldman River basin had the highest use intensity at $0.69 \mathrm{~kg}$ ai/ha.

- The Aspen Parkland ecoregion had the largest quantity of sales by ecoregion, at just over $3 \mathrm{M}$ $\mathrm{kg}$ ai.

- Agricultural pesticide use intensity for Alberta was estimated at $0.79 \mathrm{~kg}$ ai/ha. 
AAFRD. 1998. Crop Protection with Chemicals - 1998. Alberta Agriculture, Food and Rural Development. Edmonton. Agdex 606-1. 413 pp.

AAFRD. 1999a. Ecoregions, Ecodistricts and AESA Soil Quality Monitoring Sites. Alberta Agriculture, Food and Rural Development. (http://www.agric.gov.ab.ca/images/sustain/benchmarks.jpg) (October 6, 1999)

AAFRD. 1999b. Crops Grown Within the Thirteen Irrigation Districts - 1998. Alberta Agriculture, Food and Rural Development.

(http://www.agric.gov.ab.ca/irrigate/stats/main.html) (February 2, 2000)

AAFRD, 1999c. 1996 Alberta Municipality Agriculture Profile, Peace Region, Northwest Region, Northeast Region, Central Region, South Region. Alberta Agriculture, Food and Rural Development, Production Economics and Statistics Branch. Edmonton. 5 volumes.

AENV. 1998a. Pesticide Use in Alberta. Alberta Environment. Pesticide Management Program, Edmonton. 4 pp (http://www.gov.ab.ca/env/protenf/pesticide/)

AENV. 1998b. Pesticide Vendor Registrations (Blue List). June 1998. Alberta Environment, Pesticide Management Program, Edmonton. 37 pp.

AEP. 1994. Natural Regions and Subregions of Alberta: Summary. Alberta Environmental Protection. Edmonton. 18 pp.

Anderson, A-M. 1995. Overview of Pesticide Data for Alberta Surface Waters. Appendix A4 92 pp. in Cross, P. et al. Phase 2. Selection of Soil Landscape Units and Study Design Considerations for the Surface Water Quality Monitoring Program. Prepared for CAESA Water Quality Monitoring Committee. Edmonton.

CAESA. 1998. Agricultural Impact on Water Quality in Alberta: An Initial Assessment. Prepared for Canada-Alberta Environmentally Sustainable Agriculture Water Quality Committee. Alberta Agriculture, Food and Rural Development. Lethbridge. 95 pp.

CDPR. 1999. Summary of Pesticide Use.Report Data - 1998. Indexed by Chemical. California Environmental Protection Agency, California Department of Pesticide Regulation. Sacramento. $39 \mathrm{pp}$.

CPI. 2000. 1998 Sales Survey Pest Control Product in Canada. Report and Discussion. Crop Protection Institute. Etobicoke, Ontario. 5 pp.

(http://www.cropro.org/ENG/sales/sales97.htm) (April 10, 2000)

Cotton, M.M. and G. Byrtus. 1995. Pesticide Sales Trends in Alberta. Appendix A2. 66 pp in Cross, P. et al. Phase 2. Selection of Soil Landscape Units and Study Design Considerations for the Surface Water Quality Monitoring Program. Prepared for CAESA Water Quality Monitoring Committee. Edmonton.

Ecological Stratification Working Group. 1995. A National Ecological Framework for Canada. Agriculture and Agri-Food Canada, Research Branch, Centre for Land and Biological 
Resources Research and Environment Canada, State of the Environment Directorate, Ecozone Analysis Branch, Ottawa/Hull. 121 pp report and national map at 1:7 500000 scale.

Environment Canada. 1988. Surface Water Data Reference Index. Water Survey of Canada. Ottawa. 408 pp.

EPA. 1999. Pesticides Industry Sales and Usage. 1996 and 1997 Market Estimates. United States Environmental Protection Agency. Office of Pesticide Programs. Report 733-R-99-001. Washington, D.C. 39 pp.

Gregoire, F. 1997. Overview of 1995 Pesticide Sales in Quebec. Quebec Department of Environment and Wildlife, Pesticides Division. $19 \mathrm{pp}$.

Gorse, I. 1999. Bilan des ventes de pesticides au Quebec en 1997. Directions des politiques du secteur agricole, Division des pesticides. Ministere de L'Environnement du Quebec, Envirodoq EN950037, PES-14, 116 pp.

Hall, L. 1996. How Herbicides Work: Mechanisms of Action. Alberta Agriculture, Food and Rural Development, Agdex 606-2. Edmonton. 56 pp.

Hall, L., H. Beckie and T.M. Wolf. 1999. How Herbicides Work: Biology to Application. Alberta Agriculture, Food and Rural Development. Agdex 606-2. Edmonton. 134 pp.

Heap, I.M. 1997. The Occurrence of Herbicide-Resistant Weeds Worldwide. Pesticide Science. 51:235-243.

Martin, F.R.J. 1996. Addendum \#7 to Hydrology Report \#104. The Determination of Gross and Effective Drainage Areas in the Prairie Provinces. PFRA, Regina. 109 pp.

OECD, 1999. OECD Survey on the Collection and Use of Agricultural Pesticides Sales Data: Survey Results. OECD Env. Health and Safety Publications, Series on Pesticides No. 7. Paris. 40 pp.

PMRA. 1999. Voluntary Pesticide Resistance-Management Labelling Based on Target Site/Mode of Action. Regulatory Directive DIR99-06. Pest Management Regulatory Agency, Ottawa. 24 pp. (http://www.hc-sc.gc.ca/pmra-arla/dir9906-e.pdf)

Strong, W.L. and J.M. Thompson. 1995. Ecodistricts of Alberta: Summary of Biophysical Attributes. Prepared for Alberta Environmental Protection, Edmonton. 92 pp. + maps.

USDA. 2000. 1997 Census of Agriculture - State Data. US Department of Agriculture, National Agricultural Statistics Service.

(http://www.nass.usda.gov/census/census97/volume1/ca-5/cal 14.pdf) (April 10, 2000) 
Appendix 1. Chemical Groups and Active Ingredients

\begin{tabular}{|c|c|c|}
\hline Chemical Group & Active Ingredient Name & Type of Use \\
\hline \multirow[t]{21}{*}{ Alcohols } & 1,2-ETHANEDIOL & Adjuvant \\
\hline & NONYLPHENOXYPOLYETHOXYETHANOL & Adjuvant \\
\hline & OCTYLPHENOXYPOLYETHOXYETHANOL & Adjuvant \\
\hline & $\begin{array}{l}\text { OCTYLPHENOXYPOLYETHOXYETHANOL PHOSPHATE } \\
\text { ESTER }\end{array}$ & Adjuvant \\
\hline & SILOXYLATED POLYETHER & Adjuvant \\
\hline & TRIMETHYLNONYLPOLYETHOXYETHANOL & Adjuvant \\
\hline & NONYLPHENOXYPOLYETHOXYETHANOL - IODINE COMPLEX & Disinfectant \\
\hline & PROPYLENE GLYCOL & Disinfectant \\
\hline & TRIETHYLENE GLYCOL & Disinfectant \\
\hline & 2-(HYDROXYMETHYL)-2-NITRO-1,3-PROPANEDIOL & Disinfectant \\
\hline & ABAMECTIN & Insecticide \\
\hline & BUTOXYPOLYPROPYLENE GLYCOL & Insecticide \\
\hline & $\begin{array}{l}\text { 2-HYDROXYETHYL N-OCTYL SULFIDE PLUS RELATED } \\
\text { ACTIVE COMPOUNDS }\end{array}$ & Insecticide \\
\hline & S-(2-HYDROXYPROPYL)THIOMETHANE SULFONATE & Antimicrobial \\
\hline & FATTY ALCOHOLS PRESENT AS N-DECANOL & $\begin{array}{l}\text { Plant Growth } \\
\text { Regulator }\end{array}$ \\
\hline & $\begin{array}{l}\text { FATTY ALCOHOLS PRESENT AS N-DECANOL AND N- } \\
\text { OCTANOL }\end{array}$ & $\begin{array}{l}\text { Plant Growth } \\
\text { Regulator }\end{array}$ \\
\hline & BRONOPOL & Preservative \\
\hline & AZACOSTEROL HYDROCHLORIDE & Vertebrate \\
\hline & CHOLECALCIFEROL & Vertebrate \\
\hline & 3-CHLORO-1,2-PROPANEDIOL & Vertebrate \\
\hline & ERGOCALCIFEROL & Vertebrate \\
\hline \multirow[t]{22}{*}{ Amides, Anilines } & POLYACRYLAMIDE & Adjuvant \\
\hline & METALAXYL & Fungicide \\
\hline & DIPHENYLAMINE & Fungicide \\
\hline & MEFENOXAM & Fungicide \\
\hline & FOMESAFEN & Herbicide \\
\hline & PROPYZAMIDE & Herbicide \\
\hline & DIMETHENAMID & Herbicide \\
\hline & METOLACHLOR & Herbicide \\
\hline & NAPROPAMIDE & Herbicide \\
\hline & FLUMETSULAM & Herbicide \\
\hline & ISOXABEN & Herbicide \\
\hline & PROPANIL & Herbicide \\
\hline & HYDROGEN CYANAMIDE & Herbicide \\
\hline & TEBUFENOZIDE & Insecticide \\
\hline & AMITRAZ & Insecticide \\
\hline & NICLOSAMIDE & Insecticide \\
\hline & DEET PLUS RELATED ACTIVE TOLUAMIDES & Insecticide \\
\hline & 2,2-DIBROMO-3-NITRILOPROPIONAMIDE & Antimicrobial \\
\hline & NAPHTHALENEACETAMIDE & $\begin{array}{l}\text { Plant Growth } \\
\text { Regulator }\end{array}$ \\
\hline & CHLOROACETAMIDE & Preservative \\
\hline & N-METHYLOL CHLOROACETAMIDE & Preservative \\
\hline & BONE OIL & Vertebrate \\
\hline
\end{tabular}




\begin{tabular}{|c|c|c|}
\hline Chemical Group & Active Ingredient Name & Type of Use \\
\hline \multirow[t]{7}{*}{ Amino Acids } & STREPTOMYCIN & Fungicide \\
\hline & DODINE & Fungicide \\
\hline & FLAMPROP-METHYL & Herbicide \\
\hline & FLAMPROP-M-METHYL & Herbicide \\
\hline & HYDRAMETHYLNON & Insecticide \\
\hline & IMIDACLOPRID & Insecticide \\
\hline & DODECYLGUANIDINE HYDROCHLORIDE & Antimicrobial \\
\hline \multirow[t]{22}{*}{$\begin{array}{l}\text { Ammoniums, } \\
\text { Quaternary }\end{array}$} & $\begin{array}{l}\text { N-ALKYL (25\% C12, 60\% C14, 15\% C16) DIMETHYL BENZYL } \\
\text { AMMONIUM CHLORIDE }\end{array}$ & Disinfectant \\
\hline & $\begin{array}{l}\text { N-ALKYL (40\% C12, 50\% C14, 10\% C16) DIMETHYL BENZYL } \\
\text { AMMONIUM CHLORIDE }\end{array}$ & Disinfectant \\
\hline & $\begin{array}{l}\text { N-ALKYL (50\% C12, 30\% C14, } 17 \% \text { C16, 3\% C18) DIMETHYL } \\
\text { ETHYLBENZYL AMMONIUM CHLORIDE }\end{array}$ & Disinfectant \\
\hline & $\begin{array}{l}\text { N-ALKYL (68\% C12, 32\% C14) DIMETHYL ETHYLBENZYL } \\
\text { AMMONIUM CHLORIDE }\end{array}$ & Disinfectant \\
\hline & $\begin{array}{l}\text { N-ALKYL (50\% C12, 30\% C14, } 17 \% \text { C16, 3\% C18) DIMETHYL } \\
\text { BENZYL AMMONIUM CHLORIDE }\end{array}$ & Disinfectant \\
\hline & DIDECYL DIMETHYL AMMONIUM CHLORIDE & Disinfectant \\
\hline & $\begin{array}{l}\text { N-ALKYL (5\% C12, 60\% C14, 30\% C16, 5\% C18) DIMETHYL } \\
\text { BENZYL AMMONIUM CHLORIDE }\end{array}$ & Disinfectant \\
\hline & $\begin{array}{l}\text { METHYLDODECYLBENZYL TRIMETHYL AMMONIUM } \\
\text { CHLORIDE } 80 \% \text { AND METHYLDODECYLXYYYLENE } \\
\text { BIS(TRIMETHYL AMMONIUM CHLORIDE) } 20 \%\end{array}$ & Disinfectant \\
\hline & $\begin{array}{l}\text { N-ALKYL (98\% C12, 2\% C14) DIMETHYL 1-NAPHTHYLMETHYL } \\
\text { AMMONIUM CHLORIDE }\end{array}$ & Disinfectant \\
\hline & $\begin{array}{l}\text { N-ALKYL (67\% C12, } 25 \% \text { C14, } 7 \% \text { C16, 1\% C18) DIMETHYL } \\
\text { BENZYL AMMONIUM CHLORIDE }\end{array}$ & Disinfectant \\
\hline & $\begin{array}{l}\text { DIISOBUTYLPHENOXYETHOXYETHYL DIMETHYL BENZYL } \\
\text { AMMONIUM CHLORIDE }\end{array}$ & Disinfectant \\
\hline & $\begin{array}{l}\text { N-ALKYL (5\% C5-18, 61\% C12, } 23 \% \text { C14, } 11 \% \text { C16) DIMETHYL } \\
\text { BENZYL AMMONIUM CHLORIDE }\end{array}$ & Disinfectant \\
\hline & $\begin{array}{l}\text { DISTEARYL (15\% C16, 85\% C18) DIMETHYL AMMONIUM } \\
\text { CHLORIDE }\end{array}$ & Disinfectant \\
\hline & DIOCTYL DIMETHYL AMMONIUM CHLORIDE & Disinfectant \\
\hline & OCTYL DECYL DIMETHYL AMMONIUM CHLORIDE & Disinfectant \\
\hline & $\begin{array}{l}\text { N-ALKYL ( } 3 \% \text { C12, 95\% C14, } 2 \% \text { C16) DIMETHYL BENZYL } \\
\text { AMMONIUM CHLORIDE (OR: MYRISTYL DIMETHYL BENZYL } \\
\text { AMMONIUM CHLORIDE DIHYDRATE) }\end{array}$ & Disinfectant \\
\hline & DIQUAT & Herbicide \\
\hline & PARAQUAT & Herbicide \\
\hline & DIFENZOQUAT PRESENT AS METHYL SULPHATE SALT & Herbicide \\
\hline & $\begin{array}{l}\text { DIALKYL ( } 8 \% \text { C8, } 9 \% \text { C10, } 47 \% \text { C12, } 18 \% \text { C14, } 8 \% \text { C16, } 10 \% \\
\text { C18) DIMETHYL AMMONIUM CHLORIDE }\end{array}$ & Antimicrobial \\
\hline & $\begin{array}{l}\text { DIALKYL ( } 5 \% \text { C12, } 60 \% \text { C14, } 30 \% \text { C16, 5\% C18) METHYL } \\
\text { BENZYL AMMONIUM CHLORIDE }\end{array}$ & Antimicrobial \\
\hline & CHLORMEQUAT & $\begin{array}{l}\text { Plant Growth } \\
\text { Regulator }\end{array}$ \\
\hline
\end{tabular}




\begin{tabular}{|c|c|c|}
\hline Chemical Group & Active Ingredient Name & Type of Use \\
\hline & $\begin{array}{l}\text { 1-(3-CHLOROALLYL)-3,5,7-TRIAZA-1-AZONIAADAMANTANE } \\
\text { CHLORIDE (CIS ISOMER) }\end{array}$ & Preservative \\
\hline & $\begin{array}{l}\text { 3-(TRIMETHOXYSILYL)-PROPYLDIMETHYLOCTADECYL } \\
\text { AMMONIUM CHLORIDE }\end{array}$ & Preservative \\
\hline & DENATONIUM BENZOATE & Vertebrate \\
\hline \multirow{8}{*}{$\begin{array}{l}\text { Aryloxyphenoxyl } \\
\text { Acids }\end{array}$} & CLODINAFOP-PROPARGYL & Herbicide \\
\hline & DICLOFOP-METHYL & Herbicide \\
\hline & QUIZALOFOP-ETHYL & Herbicide \\
\hline & FENOXAPROP-ETHYL & Herbicide \\
\hline & FENOXAPROP-P-ETHYL (ISOMER) & Herbicide \\
\hline & FLUAZIFOP-P-BUTYL & Herbicide \\
\hline & FLUAZIFOP-BUTYL & Herbicide \\
\hline & QUIZALOFOP P-ETHYL & Herbicide \\
\hline \multirow{19}{*}{$\begin{array}{l}\text { Azoles, Diazoles, } \\
\text { Oxazoles, Thiazoles, } \\
\text { Triazoles }\end{array}$} & ETRIDIAZOLE & Fungicide \\
\hline & MYCLOBUTANIL & Fungicide \\
\hline & PROPICONAZOLE & Fungicide \\
\hline & TRIADIMENOL & Fungicide \\
\hline & TRIADIMEFON & Fungicide \\
\hline & AMITROLE & Herbicide \\
\hline & CLOMAZONE & Herbicide \\
\hline & OXADIAZON & Herbicide \\
\hline & BENTAZON & Herbicide \\
\hline & SODIUM SALT OF 2-MERCAPTOBENZOTHIAZOLE & Antimicrobial \\
\hline & PACLOBUTRAZOL & $\begin{array}{l}\text { Plant Growth } \\
\text { Regulator }\end{array}$ \\
\hline & 1,2-BENZISOTHIAZOLIN-3-ONE & Preservative \\
\hline & 2-METHYL-4-ISOTHIAZOLIN-3-ONE & Preservative \\
\hline & 5-CHLORO-2-METHYL-4-ISOTHIAZOLIN-3-ONE & Preservative \\
\hline & 2-N-OCTYL-4-ISOTHIAZOLIN-3-ONE & Preservative \\
\hline & 2-(THIOCYANOMETHYLTHIO)BENZOTHIAZOLE & Preservative \\
\hline & ZINC 2-MERCAPTOBENZOTHIAZOLE & Preservative \\
\hline & STRYCHNINE PRESENT AS ALKALOID OR AS SULPHATE & Vertebrate \\
\hline & AZACONAZOLE & Wood Preservative \\
\hline \multirow{4}{*}{$\begin{array}{l}\text { Bacillus } \\
\text { thuringiensis species }\end{array}$} & BACILLUS THURINGIENSIS BERLINER SSP KURSTAKI & Insecticide \\
\hline & BACILLUS THURINGIENSIS SSP. SAN DIEGO & Insecticide \\
\hline & BACILLUS THURINGIENSIS, SEROTYPE H-14 & Insecticide \\
\hline & BACILLUS THURINGIENSIS SSP. TENEBRIONIS & Insecticide \\
\hline \multirow{6}{*}{$\begin{array}{l}\text { Benzimadazoles, } \\
\text { Phenylpyrroles }\end{array}$} & BENOMYL & Fungicide \\
\hline & CARBENDAZIM & Fungicide \\
\hline & THIOPHANATE-METHYL & Fungicide \\
\hline & THIABENDAZOLE & Fungicide \\
\hline & FLUDIOXONIL & Fungicide \\
\hline & CARBENDAZIM-PHOSPHATE & Fungicide \\
\hline $\begin{array}{l}\text { Benzonitriles, } \\
\text { Nitriles }\end{array}$ & CHLOROTHALONIL & Fungicide \\
\hline
\end{tabular}




\begin{tabular}{|c|c|c|}
\hline Chemical Group & Active Ingredient Name & Type of Use \\
\hline & $\begin{array}{l}\text { BROMOXYNIL PRESENT AS THE ESTER OF N-OCTANOIC } \\
\text { ACID OR N-PENTANOIC ACID }\end{array}$ & Herbicide \\
\hline & DICHLOBENIL & Herbicide \\
\hline \multirow[t]{15}{*}{ Carbamates } & PROPAMOCARB HYDROCHLORIDE & Fungicide \\
\hline & ASULAM & Herbicide \\
\hline & CHLORPROPHAM & Herbicide \\
\hline & ALDICARB & Insecticide \\
\hline & AMINOCARB & Insecticide \\
\hline & PROPOXUR & Insecticide \\
\hline & BENDIOCARB & Insecticide \\
\hline & CARBARYL & Insecticide \\
\hline & CARBOFURAN & Insecticide \\
\hline & FORMETANATE HYDROCHLORIDE & Insecticide \\
\hline & METHIOCARB & Insecticide \\
\hline & METHOMYL & Insecticide \\
\hline & OXAMYL & Insecticide \\
\hline & PIRIMICARB & Insecticide \\
\hline & IODOCARB & Wood Preservative \\
\hline \multirow[t]{14}{*}{ Carboxylic Acids } & BENZOIC ACID & Adjuvant \\
\hline & GLYCOLIC ACID & Disinfectant \\
\hline & OXINE BENZOATE & Fungicide \\
\hline & ACIFLUORFEN & Herbicide \\
\hline & IMAZYPYR & Herbicide \\
\hline & IMAZAMETHABENZ & Herbicide \\
\hline & IMAZETHAPYR & Herbicide \\
\hline & IMAZAMOX & Herbicide \\
\hline & $\begin{array}{l}\text { DICAMBA PRESENT AS ACID, AS DIETHANOLAMINE SALT, } \\
\text { AS DIMETHYLAMINE SALT, OR AS BUTOXYETHYL ESTER }\end{array}$ & Herbicide \\
\hline & CLOPYRALID & Herbicide \\
\hline & $\begin{array}{l}\text { PICLORAM PRESENT AS ACID OR AS ISOOCTYL ESTERS OR } \\
\text { AS POTASSIUM SALT }\end{array}$ & Herbicide \\
\hline & $\begin{array}{l}\text { PICLORAM PRESENT AS AMINE SALTS (ALKANOLAMINE } \\
\text { SALT, DIETHANOLAMINE SALT, OR TRIISOPROPANOLAMINE } \\
\text { SALT) }\end{array}$ & Herbicide \\
\hline & TRICLOPYR & Herbicide \\
\hline & $\begin{array}{l}\text { CHLORAMBEN PRESENT AS AMMONIUM SALT OR AS } \\
\text { SODIUM SALT }\end{array}$ & Herbicide \\
\hline \multirow[t]{6}{*}{ Chlorophenols } & $\begin{array}{l}\text { 2,4,4'-TRICHLORO-2'-HYDROXYDIPHENYL ETHER [OR 5- } \\
\text { CHLORO-2(2,4-DICHLOROPHENOXYL)PHENOL] }\end{array}$ & Disinfectant \\
\hline & 4-CHLORO-3,5-XYLENOL & Disinfectant \\
\hline & SODIUM O-BENZYL-P-CHLOROPHENATE & Disinfectant \\
\hline & DICHLOROPHEN & Insecticide \\
\hline & O-BENZYL-P-CHLOROPHENOL & Antimicrobial \\
\hline & $\begin{array}{l}\text { PENTACHLOROPHENOL PLUS RELATED ACTIVE } \\
\text { CHLOROPHENOLS }\end{array}$ & Wood Preservative \\
\hline \multirow[t]{4}{*}{ Chromenones } & ROTENONE & Insecticide \\
\hline & BRODIFACOUM & Vertebrate \\
\hline & BROMADIOLONE & Vertebrate \\
\hline & WARFARIN PRESENT IN FREE FORM OR AS SODIUM SALT & Vertebrate \\
\hline
\end{tabular}




\begin{tabular}{|c|c|c|}
\hline Chemical Group & Active Ingredient Name & Type of Use \\
\hline \multirow{3}{*}{$\begin{array}{l}\text { Cyclohexanedione } \\
\text { oximes }\end{array}$} & CLETHODIM & Herbicide \\
\hline & SETHOXYDIM & Herbicide \\
\hline & TRALKOXYDIM & Herbicide \\
\hline \multirow{13}{*}{$\begin{array}{l}\text { Diazines, } \\
\text { Quinoxalines, } \\
\text { Morpholines }\end{array}$} & TRIFORINE & Fungicide \\
\hline & DIMETHOMORPH & Fungicide \\
\hline & DODEMORPH-ACETATE & Fungicide \\
\hline & CHINOMETHIONAT & Fungicide \\
\hline & FENPROPIMORPH & Fungicide \\
\hline & QUINCLORAC & Herbicide \\
\hline & PYRAZON & Herbicide \\
\hline & PYRIDATE & Herbicide \\
\hline & PYRIDABEN & Insecticide \\
\hline & ANCYMIDOL & $\begin{array}{l}\text { Plant Growth } \\
\text { Regulator }\end{array}$ \\
\hline & 6-BENZYLAMINOPURINE (OR: 6-BENZYLADENINE) & $\begin{array}{l}\text { Plant Growth } \\
\text { Regulator }\end{array}$ \\
\hline & MALEIC HYDRAZIDE & $\begin{array}{l}\text { Plant Growth } \\
\text { Regulator }\end{array}$ \\
\hline & SULFAQUINOXALINE PRESENT AS SODIUM SALT & Vertebrate \\
\hline \multirow{4}{*}{$\begin{array}{l}\text { Dicarboximides, } \\
\text { Oxathiin }\end{array}$} & IPRODIONE & Fungicide \\
\hline & VINCLOZOLIN & Fungicide \\
\hline & OXYCARBOXIN & Fungicide \\
\hline & CARBATHIIN & Fungicide \\
\hline \multirow[t]{17}{*}{ Dithiocarbamates } & FERBAM & Fungicide \\
\hline & MANEB & Fungicide \\
\hline & MANCOZEB & Fungicide \\
\hline & METIRAM & Fungicide \\
\hline & THIRAM & Fungicide \\
\hline & ZINEB & Fungicide \\
\hline & ZIRAM & Fungicide \\
\hline & NABAM & Fungicide \\
\hline & SODIUM DIMETHYLDITHIOCARBAMATE & Fungicide \\
\hline & DESMEDIPHAM & Herbicide \\
\hline & PHENMEDIPHAM & Herbicide \\
\hline & DISODIUM CYANODITHIOMIDOCARBONATE & Antimicrobial \\
\hline & POTASSIUM N-METHYLDITHIOCARBAMATE & Antimicrobial \\
\hline & $\begin{array}{l}\text { POTASSIUM N-HYDROXYMETHYL-N- } \\
\text { METHYLDITHIOCARBAMATE }\end{array}$ & Preservative \\
\hline & POTASSIUM DIMETHYLDITHIOCARBAMATE & Preservative \\
\hline & DAZOMET & Soil Fumigant \\
\hline & METAM & Soil Fumigant \\
\hline \multirow[t]{5}{*}{ Fatty Acids } & TALLOW FATTY ACID AMINE ETHOXYLATE & Adjuvant \\
\hline & TALL OIL FATTY ACIDS & Adjuvant \\
\hline & SODIUM DODECYLBENZENESULFONATE & Disinfectant \\
\hline & FATTY ACID & Herbicide \\
\hline & SOAP (HERBICIDAL) & Herbicide \\
\hline
\end{tabular}




\begin{tabular}{|c|c|c|}
\hline Chemical Group & Active Ingredient Name & Type of Use \\
\hline & SOAP & Insecticide \\
\hline & SAFER'S INSECTICIDAL SOAP & Insecticide \\
\hline & $\begin{array}{l}\text { POLY[OXYETHYLENE(DIMETHYLIMINIO)ETHYLENE(DIMETHY } \\
\text { LIMINIO)ETHYLENE DICHLORIDE] }\end{array}$ & Antimicrobial \\
\hline & $\begin{array}{l}\text { POLY[HYDROXYETHYLENE(DIMETHYLIMINIO)ETHYLENE(DI } \\
\text { METHYLIMINIO)METHYLENE DICHLORIDE] }\end{array}$ & Antimicrobial \\
\hline \multirow{5}{*}{$\begin{array}{l}\text { Halogenated } \\
\text { Hydrocarbons }\end{array}$} & METHYL BROMIDE & Insecticide \\
\hline & 1,4-BIS(BROMOACETOXY)-2-BUTENE & Antimicrobial \\
\hline & B-BROMO-B-NITROSTYRENE & Antimicrobial \\
\hline & 1,2-DIBROMO-2,4-DICYANOBUTANE & Preservative \\
\hline & DIODOFON & Preservative \\
\hline \multirow[t]{5}{*}{ Hydrocarbons } & PETROLEUM HYDROCARBON BLEND & Adjuvant \\
\hline & ASPHALT SOLIDS & Fungicide \\
\hline & NAPHTHALENE & Insecticide \\
\hline & MUSCALURE & Insecticide \\
\hline & POLYMERIZED BUTENES & Vertebrate \\
\hline \multirow[t]{3}{*}{ Indanediones } & CHLOROPHACINONE & Vertebrate \\
\hline & $\begin{array}{l}\text { DIPHACINONE PRESENT IN FREE FORM OR AS SODIUM } \\
\text { SALT }\end{array}$ & Vertebrate \\
\hline & PINDONE PRESENT IN FREE FORM OR AS SODIUM SALT & Vertebrate \\
\hline \multirow[t]{11}{*}{ Inorganic Coppers } & $\begin{array}{l}\text { COPPER AS ELEMENTAL, PRESENT AS TRIBASIC COPPER } \\
\text { SULPHATE }\end{array}$ & Fungicide \\
\hline & $\begin{array}{l}\text { COPPER THIOCYANATE (ALSO EXPRSSED IN TERMS OF } \\
\text { COPPER AS ELEMENTAL) }\end{array}$ & Fungicide \\
\hline & COPPER AS ELEMENTAL, PRESENT AS COPPER SULPHATE & Fungicide \\
\hline & $\begin{array}{l}\text { COPPER AS ELEMENTAL, PRESENT AS COPPER } \\
\text { OXYCHLORIDE }\end{array}$ & Fungicide \\
\hline & COPPER AS ELEMENTAL, PRESENT AS CUPRIC HYDROXIDE & Fungicide \\
\hline & $\begin{array}{l}\text { COPPER AS ELEMENTAL, PRESENT AS COPPER } \\
\text { TRIETHANOLAMINE COMPLEX }\end{array}$ & Herbicide \\
\hline & COPPER POWDER, METALLIC & Preservative \\
\hline & $\begin{array}{l}\text { CUPROUS OXIDE (ALSO EXPRESSED IN TERMS OF COPPER } \\
\text { AS ELEMENTAL) }\end{array}$ & Preservative \\
\hline & $\begin{array}{l}\text { COPPER AS ELEMENTAL, PRESENT AS COPPER } \\
\text { NAPHTHENATE }\end{array}$ & Wood Preservative \\
\hline & CUPRIC OXIDE & Wood Preservative \\
\hline & COPPER 8-QUINOLINOLATE & Wood Preservative \\
\hline \multirow[t]{5}{*}{ Inorganic Zincs } & ZINC OXIDE & Disinfectant \\
\hline & ZINC BORATE & Preservative \\
\hline & ZINC PHOSPHIDE & Vertebrate \\
\hline & ZINC & Wood Preservative \\
\hline & ZINC AS ELEMENTAL, PRESENT AS ZINC NAPHTHENATE & Wood Preservative \\
\hline \multirow[t]{6}{*}{ Inorganics, Other } & AMMONIUM SULPHATE & Adjuvant \\
\hline & DIAMMONIUM PHOSPHATE & Adjuvant \\
\hline & CALCIUM HYPOCHLORITE & Disinfectant \\
\hline & HYDROCHLORIC ACID & Disinfectant \\
\hline & POTASSIUM MONOPERSULPHATE & Disinfectant \\
\hline & PHOSPHORIC ACID & Disinfectant \\
\hline
\end{tabular}




\begin{tabular}{|c|c|c|}
\hline Chemical Group & Active Ingredient Name & Type of Use \\
\hline & POTASSIUM HYDROXIDE & Disinfectant \\
\hline & SODIUM BROMIDE & Disinfectant \\
\hline & SODIUM CARBONATE & Disinfectant \\
\hline & SULPHURIC ACID & Disinfectant \\
\hline & TETRAPOTASSIUM PYROPHOSPHATE & Disinfectant \\
\hline & SULPHUR (FUNGICIDE) & Fungicide \\
\hline & LIME SULPHUR OR CALCIUM POLYSULPHIDE & Fungicide \\
\hline & MERCURIC CHLORIDE & Fungicide \\
\hline & MERCUROUS CHLORIDE & Fungicide \\
\hline & CHLORINE DIOXIDE FROM SODIUM CHLORITE & Fungicide \\
\hline & SODIUM HYPOCHLORITE & Fungicide \\
\hline & AMMONIUM SULPHAMATE & Herbicide \\
\hline & FERROUS SULFATE & Herbicide \\
\hline & SODIUM CHLORATE & Herbicide \\
\hline & SODIUM METABORATE OCTAHYDRATE & Herbicide \\
\hline & SODIUM METABORATE TETRAHYDRATE & Herbicide \\
\hline & ALUMINUM PHOSPHIDE & Insecticide \\
\hline & BORAX, ANHYDROUS & Insecticide \\
\hline & BORAX PENTAHYDRATE & Insecticide \\
\hline & BORAX & Insecticide \\
\hline & BORACIC ACID & Insecticide \\
\hline & CARBON DIOXIDE & Insecticide \\
\hline & HYDROGEN PEROXIDE & Insecticide \\
\hline & SODIUM FLUORIDE & Insecticide \\
\hline & SODIUM FLUOSILICATE (OR SODIUM SILICOFLUORIDE) & Insecticide \\
\hline & SILICA AEROGEL & Insecticide \\
\hline & SILICON DIOXIDE SALT WATER FOSSILS & Insecticide \\
\hline & SULPHUR (INSECTICIDE) & Insecticide \\
\hline & IODINE & Antimicrobial \\
\hline & LITHIUM HYPOCHLORITE & Antimicrobial \\
\hline & BARIUM METABORATE MONOHYDRATE & Preservative \\
\hline & AMMONIA & Vertebrate \\
\hline & HYDROGEN CYANIDE & Vertebrate \\
\hline & SULPHUR (VERTEBRATE CONTROL) & Vertebrate \\
\hline & ARSENIC PENTOXIDE & Wood Preservative \\
\hline & DISODIUM OCTABORATE TETRAHYDRATE & Wood Presenvative \\
\hline & CHROMIC ACID & Wood Presenvative \\
\hline & POTASSIUM DICHROMATE & Wood Preservative \\
\hline \multirow{5}{*}{$\begin{array}{l}\text { Microbials (Other } \\
\text { than Bt) }\end{array}$} & AGROBACTERIUM RADIOBACTER & Fungicide \\
\hline & COLLETOTRICHUM GLOEOSPORIOIDES f.SP. MALVAE & Herbicide \\
\hline & NUCLEAR POLYHEDROSIS VIRUS OF THE GYPSY MOTH & Insecticide \\
\hline & $\begin{array}{l}\text { NUCLEAR POLYHEDROSIS VIRUS OF RED-HEADED PINE } \\
\text { SAWFLY }\end{array}$ & Insecticide \\
\hline & $\begin{array}{l}\text { NUCLEAR POLYHEDROSIS VIRUS OF DOUGLAS-FIR } \\
\text { TUSSOCK MOTH }\end{array}$ & Insecticide \\
\hline \multirow{4}{*}{$\begin{array}{l}\text { Miscellaneous (Non- } \\
\text { Classified) }\end{array}$} & N-ALKYL DIETHANOLAMINE & Adjuvant \\
\hline & N-ALKYL POLYETHOXYETHANOL & Adjuvant \\
\hline & POLYACRYLIC POLYMER & Adjuvant \\
\hline & POLYOXYALKYLATED ALKYL PHOSPHATE ESTER & Adjuvant \\
\hline
\end{tabular}




\begin{tabular}{|c|c|c|}
\hline Chemical Group & Active Ingredient Name & Type of Use \\
\hline & POLYVINYL POLYMER & Adjuvant \\
\hline & POLYOXYETHYLENE (20) SORBITAN MONOLAURATE & Adjuvant \\
\hline & $\begin{array}{l}\text { 1-(ALKYL-AMINO)-3-AMINOPROPANE HYDROCHLORIDE } \\
\text { (COMPONENT OF AMPHO 443-31) }\end{array}$ & Disinfectant \\
\hline & $\begin{array}{l}\text { 1-(ALKYL-AMINO)-3-CARBOXYMETHYLAMINOPROPANE } \\
\text { (COMPONENT OF AMPHO 443-31) }\end{array}$ & Disinfectant \\
\hline & $\begin{array}{l}\text { BUTOXYPOLYPROPOXYPOLYETHOXYETHANOL - IODINE } \\
\text { COMPLEX }\end{array}$ & Disinfectant \\
\hline & COAL TAR OILS & Disinfectant \\
\hline & MIXTURE OF 3 COMPOUNDS: BCD + DDH + DDM & Disinfectant \\
\hline & MIXTURE OF 2 COMPOUNDS: DDH + DDM & Disinfectant \\
\hline & 1,3-DICHLORO-5-ETHYL-5 METHYLHYDANTOIN & Disinfectant \\
\hline & DIPROPYLENE GLYCOL & Disinfectant \\
\hline & PARAFORMALDEHYDE & Disinfectant \\
\hline & $\begin{array}{l}\text { POLYETHOXYPOLYPROPOXYPOLYETHOXYETHANOL- } \\
\text { IODINE COMPLEX }\end{array}$ & Disinfectant \\
\hline & $\begin{array}{l}\text { ALKYL MORPHOLINIUM ETHOSULPHATE ( } 1 \% \text { C } 14,22 \% \text { C } 16 \text {, } \\
77 \% \text { C } 18)\end{array}$ & Disinfectant \\
\hline & SODIUM PARA-TERTIARY AMYLPHENATE & Disinfectant \\
\hline & SODIUM HYDROXIDE & Disinfectant \\
\hline & SODIUM LAURYL SULFATE & Disinfectant \\
\hline & CYPRODINIL & Fungicide \\
\hline & DICHLOFLUANID & Fungicide \\
\hline & ETHOXYQUIN & Fungicide \\
\hline & FORMALDEHYDE & Fungicide \\
\hline & ETHOFUMESATE & Herbicide \\
\hline & ACROLEIN & Herbicide \\
\hline & BENAZOLIN PRESENT AS DIMETHYLAMINE SALT & Herbicide \\
\hline & WATER SOLUBLE DYES & Herbicide \\
\hline & PROPARGITE & Insecticide \\
\hline & METHOPRENE & Insecticide \\
\hline & STYRENE BUTADIENE COPOLYMER RUBBER & Insecticide \\
\hline & CHLORDECONE & Insecticide \\
\hline & NATURAL GUM RESINS & Insecticide \\
\hline & KINOPRENE & Insecticide \\
\hline & B-BUTOXY-B'-THIOCYANODIETHYL ETHER & Insecticide \\
\hline & METALDEHYDE & Insecticide \\
\hline & METHYL ISOTHIOCYANATE & Insecticide \\
\hline & $\begin{array}{l}\text { SODIUM SALT OF N-(3,4-DICHLOROPHENYL)-N'-2 (2-SULFO- } \\
\text { 4-CHLOROPHENOXY)-5-CHLOROPHENYL UREA }\end{array}$ & Insecticide \\
\hline & PIPERONYL BUTOXIDE & Insecticide \\
\hline & PHEROMONE: CODLING MOTH & Insecticide \\
\hline & PHEROMONE: GRAPE BERRY MOTH & Insecticide \\
\hline & SULFOXIDE PLUS RELATED ACTIVE COMPOUNDS & Insecticide \\
\hline & $\begin{array}{l}\text { Z-11-TETRADECENYL ACETATE (OR: CIS-11-TETRADECENYL } \\
\text { ACETATE) }\end{array}$ & Insecticide \\
\hline & BEDOUKIAN TPW TECHNICAL PHEROMONE & Insecticide \\
\hline & N-ALKYL-1,3 PROPANEDIAMINE MONOBENZOATE & Antimicrobial \\
\hline & 1-ALKYL (C8-C18)-1,3-PROPANEDIAMINE ACETATE & Antimicrobial \\
\hline & 1-ALKYL C6-C18 1,3-PROPANE DIAMINE & Antimicrobial \\
\hline
\end{tabular}




\begin{tabular}{|c|c|c|}
\hline Chemical Group & Active Ingredient Name & Type of Use \\
\hline & DEHYDROABIETYLAMINE ACETATE & Antimicrobial \\
\hline & DEHYDROABIETYLAMINE ETHYLENE OXIDE & Antimicrobial \\
\hline & GLUTARALDEHYDE & Antimicrobial \\
\hline & METHYLENE BIS(THIOCYANATE) & Antimicrobial \\
\hline & $\begin{array}{l}\text { N-[A-(1-NITROETHYL)BENZYL]ETHYLENEDIAMINE, PRESENT } \\
\text { AS POTASSIUM SALT }\end{array}$ & Antimicrobial \\
\hline & $\begin{array}{l}\text { OXYDIETHYLENE BIS(ALKYL DIMETHYL AMMONIUM } \\
\text { CHLORIDE) }\end{array}$ & Antimicrobial \\
\hline & DICHLORFLURECOL-METHYL & $\begin{array}{l}\text { Plant Growth } \\
\text { Regulator }\end{array}$ \\
\hline & FLURECOL-METHYL & $\begin{array}{l}\text { Plant Growth } \\
\text { Regulator }\end{array}$ \\
\hline & BENZYL BROMOACETATE & Preservative \\
\hline & 2,2-OXYBIS (4,4,6-TRIMETHYL-1,3,2-DIOXABORINANE) & Preservative \\
\hline & 2,2'-DITHIOBISBENZAMIDE & Preservative \\
\hline & DIPHENYLSTIBINE 2-ETHYLHEXOATE & Preservative \\
\hline & OXIRANE DERIVATIVES (50\% MINIMUM) & Preservative \\
\hline & $\begin{array}{l}\text { 2,2'-(1-METHYLTRIMETHYLENEDIOXY)BIS-(4-METHYL-1,3,2- } \\
\text { DIOXABORINANE) }\end{array}$ & Preservative \\
\hline & ETHYLENE OXIDE & Soil Fumigant \\
\hline & DIMETHYL ALKYL AMINE & Vertebrate \\
\hline & PUTRESCENT WHOLE EGG SOLIDS & Vertebrate \\
\hline & METHYL NONYL KETONE & Vertebrate \\
\hline \multirow[t]{10}{*}{ Nitro Derivatives } & DICHLORAN & Fungicide \\
\hline & DINOCAP PLUS RELATED ACTIVE COMPOUNDS & Fungicide \\
\hline & OXYFLUORFEN & Herbicide \\
\hline & DINOSEB PRESENT IN FREE FORM & Herbicide \\
\hline & ETHALFLURALIN & Herbicide \\
\hline & PENDIMETHALIN & Herbicide \\
\hline & TRIFLURALIN & Herbicide \\
\hline & BROMETHALIN & Vertebrate \\
\hline & @-@,@-TRIFLUORO-4-NITRO-M-CRESOL & Vertebrate \\
\hline & DINITROPHENOL & Wood Preservative \\
\hline \multirow{14}{*}{$\begin{array}{l}\text { Oils, Mineral and } \\
\text { Vegetable }\end{array}$} & PARAFFIN BASE MINERAL OIL (ADJUVANT) & Adjuvant \\
\hline & $\begin{array}{l}\text { MINERAL OIL (HERBICIDAL OR PLANT GROWTH } \\
\text { REGULATOR) }\end{array}$ & Adjuvant \\
\hline & PARAFFIN BASE PETROLEUM OIL & Adjuvant \\
\hline & VEGETABLE OIL & Adjuvant \\
\hline & SURFACTANT MIXTURE & Adjuvant \\
\hline & SURFACTANT BLEND & Adjuvant \\
\hline & PINE OIL & Disinfectant \\
\hline & XYLENOLS & Disinfectant \\
\hline & CITRONELLA TERPENE & Insecticide \\
\hline & OIL OF CITRONELLA & Insecticide \\
\hline & $\begin{array}{l}\text { ARTIFICIAL ESSENTIAL OIL BLEND -- SEE CHEMISTRY FILE } \\
\text { FOR LIST OF OILS }\end{array}$ & Insecticide \\
\hline & OIL OF LAVENDER & Insecticide \\
\hline & MINERAL OIL (INSECTICIDAL OR ADJUVANT) & Insecticide \\
\hline & OIL OF LEMONGRASS & Insecticide \\
\hline
\end{tabular}




\begin{tabular}{|c|c|c|}
\hline Chemical Group & Active Ingredient Name & Type of Use \\
\hline & $\begin{array}{l}\text { OLEORESIN CAPSICUM (OF WHICH PRINCIPAL COMPONENT } \\
\text { IS CAPSAICIN) }\end{array}$ & Vertebrate \\
\hline & PIPERINE & Vertebrate \\
\hline & OIL OF BLACK PEPPER & Vertebrate \\
\hline & CEDAR LEAF OIL & Vertebrate \\
\hline & MUSTARD OIL & Vertebrate \\
\hline & $\begin{array}{l}\text { BLEND OF OILS: OF LEMONGRASS, OF CITRONELLA, OF } \\
\text { ORANGE, OF BERGAMOT; GERANIOL, IONONE ALPHA, } \\
\text { METHYL SALICYLATE AND ALLYLISOTHIOCYANATE }\end{array}$ & Vertebrate \\
\hline \multirow[t]{8}{*}{ Organic Acids } & ACETIC ACID & Disinfectant \\
\hline & CITRIC ACID & Disinfectant \\
\hline & TCA PRESENT AS SODIUM SALT & Herbicide \\
\hline & DAMINOZIDE & $\begin{array}{l}\text { Plant Growth } \\
\text { Regulator }\end{array}$ \\
\hline & GIBBERELLIC ACID & $\begin{array}{l}\text { Plant Growth } \\
\text { Regulator }\end{array}$ \\
\hline & $\begin{array}{l}\text { NAPHTHALENE ACETIC ACID (PRESENT AS ETHYL ESTER, } \\
\text { SODIUM SALT, OR AS AMMONIUM SALT) }\end{array}$ & $\begin{array}{l}\text { Plant Growth } \\
\text { Regulator }\end{array}$ \\
\hline & PIMARICIN & Preservative \\
\hline & SODIUM MONOFLUOROACETATE & Vertebrate \\
\hline \multirow[t]{13}{*}{ Organochlorines } & QUINTOZENE & Fungicide \\
\hline & CHLORONEB & Fungicide \\
\hline & DICHLONE & Fungicide \\
\hline & DIENOCHLOR & Insecticide \\
\hline & ENDOSULFAN & Insecticide \\
\hline & GAMMA-BHC FROM LINDANE & Insecticide \\
\hline & DICOFOL & Insecticide \\
\hline & METHOXYCHLOR & Insecticide \\
\hline & PARADICHLOROBENZENE & Insecticide \\
\hline & BIS(TRICHLOROMETHYL)SULFONE & Antimicrobial \\
\hline & CHLORFLURECOL-METHYL & $\begin{array}{l}\text { Plant Growth } \\
\text { Regulator }\end{array}$ \\
\hline & CHLOROPICRIN & Soil Fumigant \\
\hline & 1,3-DICHLOROPROPENE & Soil Fumigant \\
\hline \multirow[t]{11}{*}{ Organometallics } & TRIBUTYLTIN OXIDE & Fungicide \\
\hline & TRI-N-BUTYLTIN CHLORIDE & Fungicide \\
\hline & TRI-N-BUTYLTIN FLUORIDE & Fungicide \\
\hline & TRI-N-BUTYLTIN MALEATE & Fungicide \\
\hline & TRI-N-BUTYLTIN METHACRYLATE & Fungicide \\
\hline & DI(PHENYLMERCURIC)DODECENYL SUCCINATE & Fungicide \\
\hline & $\begin{array}{l}\text { MERCURY AS ELEMENTAL, PRESENT AS PHENYLMERCURIC } \\
\text { SALTS OF DODECENYL SUCCINIC AND TALL OIL FATTY } \\
\text { ACIDS }\end{array}$ & Fungicide \\
\hline & PHENYLMERCURIC ACETATE & Fungicide \\
\hline & N-PHENYL MERCURY 2-ETHYLHEXYL MALEATE & Fungicide \\
\hline & PHENYLMERCURIC OLEATE & Fungicide \\
\hline & $\begin{array}{l}\text { ARSENIC AS ELEMENTAL, PRESENT AS DODECYL AND } \\
\text { OCTYL AMMONIUM METHYL ARSENATES }\end{array}$ & Herbicide \\
\hline
\end{tabular}




\begin{tabular}{|c|c|c|}
\hline Chemical Group & Active Ingredient Name & Type of Use \\
\hline & $\begin{array}{l}\text { ARSENIC AS ELEMENTAL, PRESENT AS MONOSODIUM } \\
\text { METHANE ARSONATE }\end{array}$ & Herbicide \\
\hline & FENBUTATIN OXIDE & Insecticide \\
\hline & 10,10'-OXYBIS(PHENOXARSINE) & Preservative \\
\hline \multirow[t]{34}{*}{ Organophosphorous } & FOSETYL-AL & Fungicide \\
\hline & PYRAZOPHOS & Fungicide \\
\hline & BENSULIDE & Herbicide \\
\hline & TEMEPHOS & Insecticide \\
\hline & ACEPHATE & Insecticide \\
\hline & AZAMETHIPHOS & Insecticide \\
\hline & CHLORFENVINPHOS & Insecticide \\
\hline & COUMAPHOS & Insecticide \\
\hline & TERBUFOS & Insecticide \\
\hline & DIMETHOATE & Insecticide \\
\hline & DISULFOTON & Insecticide \\
\hline & CHLORPYRIFOS & Insecticide \\
\hline & DICHLORVOS PLUS RELATED ACTIVE COMPOUNDS & Insecticide \\
\hline & ETHION & Insecticide \\
\hline & FENSULFOTHION & Insecticide \\
\hline & FENITROTHION & Insecticide \\
\hline & FENTHION & Insecticide \\
\hline & TETRACHLORVINPHOS & Insecticide \\
\hline & AZINPHOS-METHYL & Insecticide \\
\hline & MALATHION & Insecticide \\
\hline & METHIDATHION & Insecticide \\
\hline & METHAMIDOPHOS & Insecticide \\
\hline & NALED & Insecticide \\
\hline & OXYDEMETON-METHYL & Insecticide \\
\hline & PHORATE & Insecticide \\
\hline & PHOSALONE & Insecticide \\
\hline & PHOSMET & Insecticide \\
\hline & PARATHION & Insecticide \\
\hline & SULFOTEP PLUS RELATED ACTIVE COMPOUNDS & Insecticide \\
\hline & DIAZINON & Insecticide \\
\hline & CROTOXYPHOS & Insecticide \\
\hline & IODOFENPHOS & Insecticide \\
\hline & PROPETAMPHOS & Insecticide \\
\hline & DIMETHOXANE & Antimicrobial \\
\hline \multirow[t]{10}{*}{ Phenols } & COAL TAR ACIDS & Disinfectant \\
\hline & O-PHENYLPHENOL & Disinfectant \\
\hline & ORTHO-PHENYLPHENOL (POTASSIUM SALT) & Disinfectant \\
\hline & SODIUM O-PHENYLPHENATE & Disinfectant \\
\hline & P-TERT AMYL PHENOL & Disinfectant \\
\hline & M-CRESOL & Fungicide \\
\hline & 2,4-XYLENOL (OR 2,4-DIMETHYLPHENOL) & Fungicide \\
\hline & $\begin{array}{l}\text { CRESYLIC ACID (OR: PHENOLIC HOMOLOGUES; A MIXTURE } \\
\text { OF CRESOLS, XYLENOLS, ETHYL PHENOLS AND HIGHER } \\
\text { MOLECULAR WEIGHT PHENOLS) }\end{array}$ & Insecticide \\
\hline & 2-BROMO-4'-HYDROXYACETOPHENONE & Antimicrobial \\
\hline & 2-(P-HYDROXYPHENYL)GLYOXYLOHYDROXYMOYL & Antimicrobial \\
\hline
\end{tabular}




\begin{tabular}{|c|c|c|}
\hline Chemical Group & Active Ingredient Name & Type of Use \\
\hline & CHLORIDE & \\
\hline & CREOSOTE & Wood Preservative \\
\hline \multirow[t]{18}{*}{ Phenoxy Acids } & DICHLORPROP PRESENT AS DIMETHYLAMINE SALT & Herbicide \\
\hline & $\begin{array}{l}\text { DICHLORPROP PRESENT AS BUTOXYETHYL ESTER OR AS } \\
\text { ISOOCTYL ESTER }\end{array}$ & Herbicide \\
\hline & $\begin{array}{l}\text { 2,4-DB PRESENT AS MIXED BUTYL ESTERS OR AS } \\
\text { ISOOCTYL ESTERS }\end{array}$ & Herbicide \\
\hline & 2,4-D PRESENT AS ACID & Herbicide \\
\hline & $\begin{array}{l}\text { 2,4-D PRESENT AS AMINE SALTS (DIMETHYLAMINE SALT, } \\
\text { DIETHANOLAMINE SALT, OR OTHER AMINE SALTS) }\end{array}$ & Herbicide \\
\hline & 2,4-D PRESENT AS LOW VOLATILE ESTERS & Herbicide \\
\hline & 2,4-D PRESENT AS SODIUM SALT & Herbicide \\
\hline & MCPA PRESENT AS ACID & Herbicide \\
\hline & $\begin{array}{l}\text { MCPA PRESENT AS AMINE SALTS (diethanolamine, } \\
\text { dimethylamine, or mixed amines) }\end{array}$ & Herbicide \\
\hline & MCPA PRESENT AS ESTERS & Herbicide \\
\hline & MCPA PRESENT AS POTASSIUM SALT OR AS SODIUM SALT & Herbicide \\
\hline & MCPB PRESENT AS SODIUM SALT & Herbicide \\
\hline & MCPB PRESENT AS ISOMER SPECIFIC & Herbicide \\
\hline & MECOPROP (D-ISOMER) PRESENT AS POTASSIUM SALT & Herbicide \\
\hline & MECOPROP (D-ISOMER) PRESENT AS AMINE SALTS & Herbicide \\
\hline & MECOPROP (D-ISOMER) PRESENT AS ACID & Herbicide \\
\hline & MECOPROP D-ISOMER & Herbicide \\
\hline & 4-CPA & $\begin{array}{l}\text { Plant Growth } \\
\text { Regulator }\end{array}$ \\
\hline \multirow{9}{*}{$\begin{array}{l}\text { Phosphonic Acids, } \\
\text { Phosphinic Acids }\end{array}$} & GLUFOSINATE AMMONIUM & Herbicide \\
\hline & ISOPROPYLAMINE SALT OF GLYPHOSATE & Herbicide \\
\hline & MONO-AMMONIUM SALT OF GLYPHOSATE & Herbicide \\
\hline & GLYPHOSATE ACID & Herbicide \\
\hline & TRIMETHYLSULFONIUM SALT OF GLYPHOSATE & Herbicide \\
\hline & FOSAMINE AMMONIUM & Herbicide \\
\hline & FONOFOS & Insecticide \\
\hline & TRICHLORFON & Insecticide \\
\hline & ETHEPHON & $\begin{array}{l}\text { Plant Growth } \\
\text { Regulator }\end{array}$ \\
\hline \multirow[t]{7}{*}{ Phthalic Acids } & CAPTAN & Fungicide \\
\hline & FOLPET & Fungicide \\
\hline & NAPTALAM PRESENT AS ACID OR AS SODIUM SALT & Herbicide \\
\hline & CHLORTHAL PRESENT AS ACID OR AS DIMETHYL ESTER & Herbicide \\
\hline & ENDOTHALL PRESENT AS DIPOTASSIUM SALT & Herbicide \\
\hline & DIMETHYL PHTHALATE & Insecticide \\
\hline & N-OCTYL BICYCLOHEPTENE DICARBOXIMIDE & Insecticide \\
\hline \multirow{6}{*}{$\begin{array}{l}\text { Pyrethroids, } \\
\text { Pyrethrins }\end{array}$} & D-CIS, TRANS ALLETHRIN & Insecticide \\
\hline & D-TRANS ALLETHRIN & Insecticide \\
\hline & ALLETHRIN & Insecticide \\
\hline & CYFLUTHRIN & Insecticide \\
\hline & CYPERMETHRIN & Insecticide \\
\hline & DELTAMETHRIN & Insecticide \\
\hline
\end{tabular}




\begin{tabular}{|c|c|c|}
\hline Chemical Group & Active Ingredient Name & Type of Use \\
\hline & FENVALERATE & Insecticide \\
\hline & FLUCYTHRINATE & Insecticide \\
\hline & FLUVALINATE & Insecticide \\
\hline & TETRAMETHRIN PLUS RELATED ACTIVE COMPOUNDS & Insecticide \\
\hline & PERMETHRIN & Insecticide \\
\hline & PYRETHRINS & Insecticide \\
\hline & RESMETHRIN & Insecticide \\
\hline & TEFLUTHRIN & Insecticide \\
\hline & CYHALOTHRIN-LAMDA (PROPOSED) & Insecticide \\
\hline & CYPHENOTHRIN & Insecticide \\
\hline & D-PHENOTHRIN & Insecticide \\
\hline & TRALOMETHRIN & Insecticide \\
\hline \multirow[t]{7}{*}{ Pyridines } & SODIUM OMADINE & Disinfectant \\
\hline & DITHIOPYR & Herbicide \\
\hline & FLUROXYPYR 1-METHYLHEPTYYLESTER & Herbicide \\
\hline & NICOTINE PRESENT AS ALKALOID OR AS SULPHATE & Insecticide \\
\hline & DI-N-PROPYL ISOCINCHOMERONATE & Insecticide \\
\hline & PYRIPROXYFEN & Insecticide \\
\hline & 4-AMINOPYRIDINE & Vertebrate \\
\hline \multirow{12}{*}{$\begin{array}{l}\text { Sulfonylureas, } \\
\text { Uracils }\end{array}$} & CHLORIMURON-ETHYL & Herbicide \\
\hline & $\begin{array}{l}\text { 2-CHLORO-N-[(4-METHOXY-6-METHYL-1,3,5-TRIAZIN-2 } \\
\text { YL)AMINOCARBONYL]BENZENE SULFONAMIDE } \\
\text { (Chlorsulfuron) }\end{array}$ & Herbicide \\
\hline & RIMSULFURON & Herbicide \\
\hline & ETHAMETSULFURON-METHYL & Herbicide \\
\hline & METSULFURON-METHYL & Herbicide \\
\hline & $\begin{array}{l}\text { 2-[IN[4-METHOXY-6-METHYL-1,3,5-TRIAZINE-2-YL]-N- } \\
\text { METHYLAMINOCARBONYL]AMINOSULFONYL]-METHYL } \\
\text { ESTER BENZOIC ACID (Tribenuron methyl) }\end{array}$ & Herbicide \\
\hline & THIFENSULFURON METHYL & Herbicide \\
\hline & NICOSULFURON & Herbicide \\
\hline & PROSULFURON & Herbicide \\
\hline & TRIASULFURON & Herbicide \\
\hline & $\begin{array}{l}\text { BROMACIL PRESENT IN FREE FORM, AS DIMETHYLAMINE } \\
\text { SALT, OR AS LITHIUM SALT }\end{array}$ & Herbicide \\
\hline & TERBACIL & Herbicide \\
\hline \multirow[t]{6}{*}{ Thiocarbamates } & EPTC & Herbicide \\
\hline & PEBULATE & Herbicide \\
\hline & CYCLOATE & Herbicide \\
\hline & BUTYLATE & Herbicide \\
\hline & TRIALLATE & Herbicide \\
\hline & VERNOLATE & Herbicide \\
\hline \multirow{5}{*}{$\begin{array}{l}\text { Triazines, } \\
\text { Triazinones, } \\
\text { Tetrazines }\end{array}$} & POTASSIUM DICHLORO-S-TRIAZINETRIONE & Disinfectant \\
\hline & SODIUM DICHLORO-S-TRIAZINETRIONE & Disinfectant \\
\hline & ANILAZINE & Fungicide \\
\hline & ATRAZINE PLUS RELATED ACTIVE TRIAZINES & Herbicide \\
\hline & METRIBUZIN & Herbicide \\
\hline
\end{tabular}




\begin{tabular}{|c|c|c|}
\hline Chemical Group & Active Ingredient Name & Type of Use \\
\hline & CYANAZINE & Herbicide \\
\hline & PROMETON PLUS RELATED ACTIVE TRIAZINES & Herbicide \\
\hline & PROMETRYNE PLUS RELATED ACTIVE TRIAZINES & Herbicide \\
\hline & SIMAZINE PLUS RELATED ACTIVE TRIAZINES & Herbicide \\
\hline & HEXAZINONE & Herbicide \\
\hline & CLOFENTEZINE & Insecticide \\
\hline & CYROMAZINE & Insecticide \\
\hline & TRICHLORO-S-TRIAZINETRIONE & Antimicrobial \\
\hline & HEXAHYDRO-1,3,5-TRIETHYL-S-TRIAZINE & Preservative \\
\hline & HEXAHYDRO-1,3,5-TRIS(2-HYDROXYETHYL)-S-TRIAZINE & Preservative \\
\hline \multirow[t]{10}{*}{ Urea Derivatives } & DIFLUBENZURON & Adjuvant \\
\hline & DIURON & Herbicide \\
\hline & LINURON & Herbicide \\
\hline & MONOLINURON & Herbicide \\
\hline & METOBROMURON & Herbicide \\
\hline & SIDURON & Herbicide \\
\hline & TEBUTHIURON & Herbicide \\
\hline & MONURON & Herbicide \\
\hline & HALANE & Insecticide \\
\hline & 1-BROMO-3-CHLORO-5,5-DIMETHYLHYDANTOIN & Antimicrobial \\
\hline
\end{tabular}


Appendix 2. Herbicide Groups Based on Sites of Action for Resistance Management

\begin{tabular}{|c|c|}
\hline Resistance Group and Site of Action & Active Ingredient \\
\hline $\begin{array}{l}\text { 1. (Acetyl CoA carboxylase (ACCase) } \\
\text { inhibitors) }\end{array}$ & $\begin{array}{l}\text { Clodinafop-propargyl } \\
\text { Diclofop-methyl } \\
\text { Fenoxaprop-ethyl } \\
\text { Fenoxaprop-p-ethyl } \\
\text { Fluazifop-p-butyl } \\
\text { Fluazifop-butyl } \\
\text { Quizalofop-ethyl } \\
\text { Quizalofop-p-ethyl } \\
\text { Clethodim } \\
\text { Sethoxydim } \\
\text { Tralkoxydim }\end{array}$ \\
\hline $\begin{array}{l}2 \text { (Acetolactate synthase/aceto-hydroxyacid } \\
\text { synthase (ALS/AHAS) inhibitors) }\end{array}$ & $\begin{array}{c}\text { Chlorimuron } \\
\text { Chlorsulfuron } \\
\text { Ethamethsulfuron-methyl } \\
\text { Metsulfuron-methyl } \\
\text { Nicosulfuron } \\
\text { Prosulfuron } \\
\text { Rimsulfuron } \\
\text { Sulfosulfuron } \\
\text { Thifensulfuron-methyl } \\
\text { Triasulfuron } \\
\text { Tribenuron-methyl } \\
\text { Triflusulfuron-methyl } \\
\text { Imazmethabenz } \\
\text { Imazamox } \\
\text { Imazapyr } \\
\text { Imazamethapyr } \\
\text { Flumetsulam }\end{array}$ \\
\hline 3 (Microtubule assembly inhibitors) & $\begin{array}{c}\text { Ethalfluralin } \\
\text { Pendimethalin } \\
\text { Trifluraliln } \\
\text { Dithiopyr } \\
\text { Chlorthal-dimethyl (DCPA) }\end{array}$ \\
\hline 4 (Synthetic auxins) & $\begin{array}{c}\text { 2,4-D (acid, amines, esters, sodium \& } \\
\text { potassium salts) } \\
\text { 2,4-DB (isomer specific, sodium salt) } \\
\text { Dichlorprop (2,4-DP) } \\
\text { MCPA (acid, amines, esters, sodium \& } \\
\text { potassium salts) } \\
\text { MCPB } \\
\text { Mecoprop (MCPP)(acid, amine salt) }\end{array}$ \\
\hline
\end{tabular}




\begin{tabular}{|c|c|}
\hline Resistance Group and Site of Action & Active Ingredient \\
\hline & $\begin{array}{c}\text { Dicamba } \\
\text { Clopyralid } \\
\text { Fluroxypyr } \\
\text { Picloram (acid, ester or amine \& potassium } \\
\text { salts) } \\
\text { Triclopyr } \\
\text { Quinclorac } \\
\text { Diflufenzopyr }\end{array}$ \\
\hline $\begin{array}{l}5 \text { (Photosynthesis inhibitor at photosystem (PS) } \\
\text { II Site A) }\end{array}$ & $\begin{array}{c}\text { Atrazine } \\
\text { Cyanazine } \\
\text { Prometon } \\
\text { Prometryn } \\
\text { Simazine } \\
\\
\text { Hexazinone } \\
\text { Metribuzin } \\
\text { Bromacil } \\
\text { Terbacil } \\
\text { Pyrazon } \\
\text { Desmedipham } \\
\text { Phenmedipham }\end{array}$ \\
\hline $\begin{array}{l}6 \text { (Similar to Group 5, but different binding } \\
\text { behavior) }\end{array}$ & $\begin{array}{c}\text { Bromoxynil } \\
\text { Bentazon } \\
\text { Pyridate }\end{array}$ \\
\hline 7 (Photsynthesis inhibitors at PS II Site B) & $\begin{array}{c}\text { Diuron } \\
\text { Linuron } \\
\text { Metobromuron } \\
\text { Monolinuron } \\
\text { Siduron } \\
\text { Teburthiuron } \\
\text { Propanil }\end{array}$ \\
\hline $\begin{array}{l}8 \text { (Lipid synthesis inhibitors - not ACCase } \\
\text { inhibition) }\end{array}$ & $\begin{array}{l}\text { Butylate } \\
\text { Cycloate } \\
\text { EPTC } \\
\text { Pebulate } \\
\text { Triallate } \\
\text { Vernolate } \\
\text { Bensulide } \\
\text { Difenzoquat } \\
\end{array}$ \\
\hline 9 (EPSP* synthase inhibitors) & $\begin{array}{l}\text { Glyphosate (acid, monoammonium, } \\
\text { isopropylamine or trimethylsulfonium salt) }\end{array}$ \\
\hline 10 (Glutamine synthetase inhibitors) & Glufosinate ammonium \\
\hline
\end{tabular}




\begin{tabular}{|c|c|}
\hline Resistance Group and Site of Action & Active Ingredient \\
\hline $\begin{array}{l}11 \text { (Bleaching: Carotenoid biosynthesis } \\
\text { inhibitors) }\end{array}$ & Amitrole \\
\hline $\begin{array}{l}14 \text { (Protoporphyrinogen oxidase (PPO) } \\
\text { inhibitors) }\end{array}$ & $\begin{array}{l}\text { Acifluorfen } \\
\text { Fomesafen } \\
\text { Oxyfluorfen } \\
\text { Oxadiazon }\end{array}$ \\
\hline 15 (Unknown) & $\begin{array}{l}\text { Metolachlor } \\
\text { s-metolachlor } \\
\text { Propyzamide } \\
\text { Dimethenamid } \\
\text { Napropamide }\end{array}$ \\
\hline 16 (Unknown) & Ethofumesate \\
\hline 17 (Unknown) & Arsenic (MSMA) \\
\hline 19 (Indoleacetic acid action inhibitors) & Naptalam \\
\hline \multicolumn{2}{|l|}{20 (Inhibits cell wall synthesis Site A) } \\
\hline 22 (Photo systems I-electron diverters) & $\begin{array}{l}\text { Diquat } \\
\text { Paraquat }\end{array}$ \\
\hline 23 (Mitosis inhibitors) & Chlorpropham \\
\hline 25 (Unknown) & Flamprop-methyl \\
\hline Non classified Herbicides & $\begin{array}{c}\text { Acrolein } \\
\text { Benazolin } \\
\text { Chloramben } \\
\text { Copper as elemental } \\
\text { Ferrous Sulfate } \\
\text { Endothall } \\
\text { Monuron } \\
\text { Sodium Chlorate } \\
\text { Sodium Metaborate Tetrahydrate }\end{array}$ \\
\hline
\end{tabular}

*Enolpyruvylshikimate-3-phosphate 


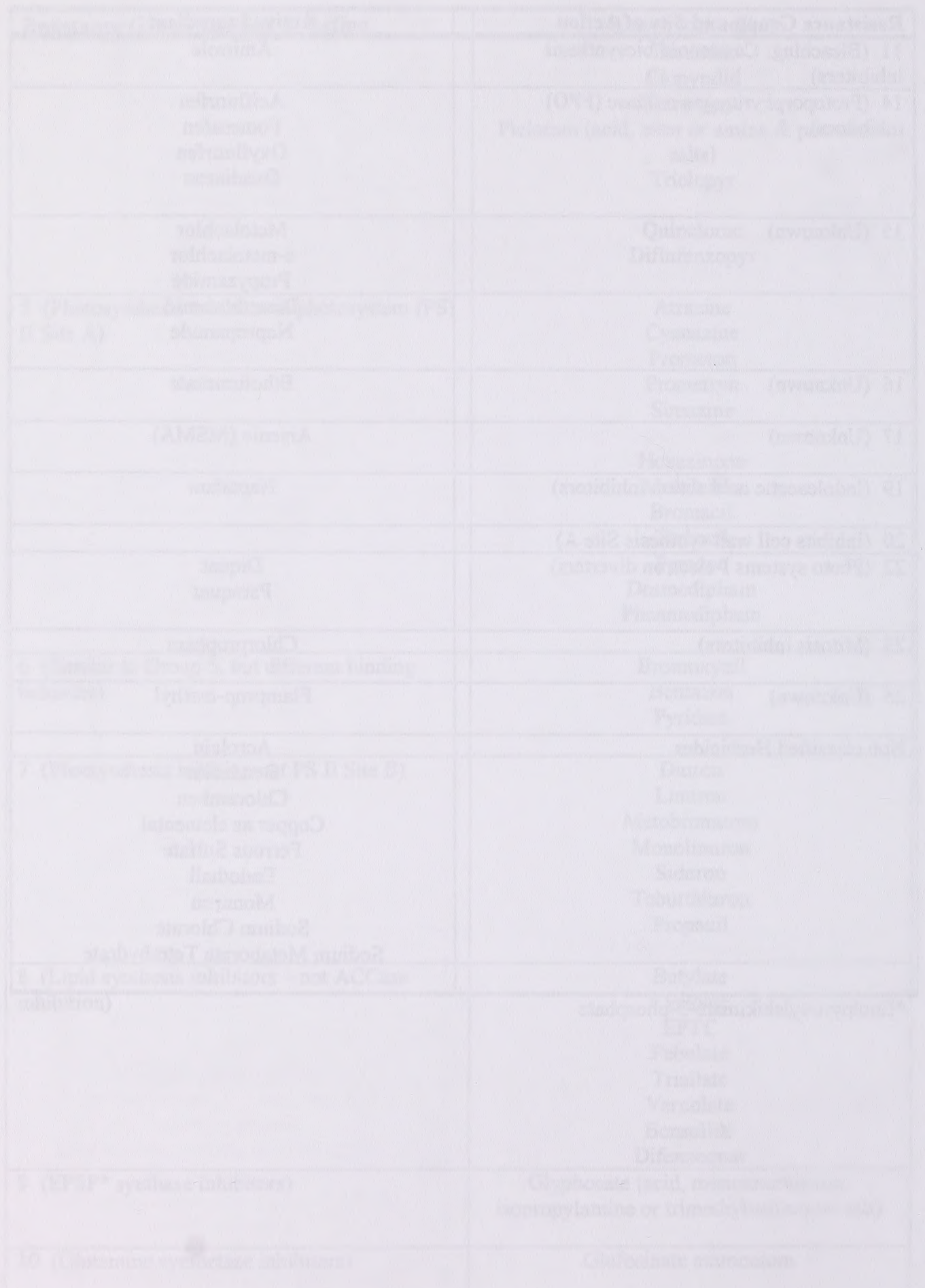



